\title{
Site U1381
}

\author{
Expedition 334 Scientists $^{2}$
}

\section{Chapter contents}

Background and objectives.......... 1

Operations.................... 2

Lithostratigraphy and petrology ........ 2

Paleontology and biostratigraphy .......4

Structural geology............... 5

Geochemistry and microbiology. . . . . . 6

Physical properties . . . . . . . . . 7

Paleomagnetism ................ 9

References................... 10

Figures................. 12

Tables...................... 41

1Expedition 334 Scientists, 2012. Site U1381. In Vannucchi, P., Ujiie, K., Stroncik, N., Malinverno, A., and the Expedition 334 Scientists, Proc. IODP, 334: Tokyo (Integrated Ocean Drilling Program Management International, Inc.). doi:10.2204/iodp.proc.334.106.2012

'Expedition 334 Scientists' addresses.

\section{Background and objectives}

The primary objective of Integrated Ocean Drilling Program (IODP) Expedition 334 was to sample and quantify the input into the seismogenic zone of an erosive subduction margin. Although the main transfer of material to the seismogenic zone is implied to come from the upper plate, the characteristics of the downward-moving plate entering the Costa Rica Subduction Zone are essential to constrain the system. This situation is particularly true in the area of the Costa Rica Seismogenic Project (CRISP), as this area is characterized by the subduction of a prominent aseismic ridge, the Cocos Ridge. In this context, IODP Site U1381 (proposed Site CRIS-1A) served as a reference site.

Site U1381 is a key site for characterizing the material input into the subduction zone, considering both the composition and mass of the sediment cover and basement rocks as well as the fluids. In erosive margins, fluids are thought to trigger the hydrofracturing processes of the upper plate and to control the strength of the plate boundary. According to existing models of erosive margins, sediments are inferred to play a minor role in the input to the seismogenic zone. The role of the igneous basement of the incoming plate is less well established. Here we target the fluids circulating in the upper oceanic crust, since a vigorous hydrologic system was discovered offshore Nicoya Peninsula during Ocean Drilling Program (ODP) Legs 170 and 205 (Kimura, Silver, Blum, et al., 1997; Morris, Villinger, Klaus, et al., 2003). The importance of the hydrological activity in the subducting oceanic plate is just beginning to be appreciated (Silver et al., 2000). The igneous crust of the incoming Cocos plate shows a significant along trench strike variability related to its origin at either the East Pacific Rise or the Cocos-Nazca spreading center. It is also characterized by a different hydrologic system compared to the crust subducted of the Nicoya Peninsula. Heat flux measurements revealed high heat flow in the Cocos Ridge area in contrast with the low values of the smooth crust offshore Nicoya Peninsula (Fisher et al., 2003; I. Grevemeyer, unpubl. data). The upper crust in the Cocos Ridge area appears to be well layered and probably very porous (von Huene et al., 2000). Thus the contribution from the lower plate to the fluid circulation could be significant, and its characterization has important consequences for the investigation of the fluid system at the aseismic/seismic boundary during CRISP Program B. 
Site U1381 is located along Seismic BGR99 Line 7 (Fig. F1), $50 \mathrm{~km}$ offshore Osa Peninsula and $43 \mathrm{~km}$ from Caño Island. Site U1381 is in a basement-relative high at common midpoint (CMP) 5750 $\left(8^{\circ} 25.7150^{\prime} \mathrm{N}, 84^{\circ} 9.4690^{\prime} \mathrm{W}\right)$ at 2067 meters below sea level (mbsl). This location is critical because basement-relative highs, thought to act as major fluid discharge areas, have the best potential to record traces of vigorous fluid flow. The seismic section indicates a $120 \mathrm{~m}$ thick sediment section resting on high reflective basement interpreted as Cocos Ridge igneous crust. Paleomagnetic data constrain the age of this portion of Cocos Ridge to $14 \mathrm{Ma}$ (Barckhausen et al., 2001). The sedimentary section has been interpreted as formed by pelagic and hemipelagic sediment. The sediment thickness along the seismic transect (southwest-northeast) is variable. This is in accordance with the relief of Cocos Ridge (basement). This relief can be partly correlated with normal faulting (CMP 4600 and 4800 in Fig. F1), even though faulting is not a particularly strong characteristic of the subducting plate in this region.

\section{Operations Transit to Site U1381}

After a $11.4 \mathrm{nmi}$ transit to Site U1381 from Site U1380, the vessel stabilized over Site U1381 at 2133 $\mathrm{h}$ (Universal Time Coordinated $-6 \mathrm{~h}$ ) on 8 April 2011. The position reference was a combination of GPS signals and a single acoustic beacon. The positioning beacon was deployed at $2152 \mathrm{~h}$ on 8 April and recovered at $1527 \mathrm{~h}$ on 12 April.

\section{Site U1381}

Two holes were cored at this site (Table T1). Hole U1381A was cored to $164.1 \mathrm{mbsf}$ with a 978 inch rotary core barrel (RCB) core bit and a $171.13 \mathrm{~m}$ long bottom-hole assembly (BHA). Coring continued through Core 334-U1381A-26R to 164.1 meters below seafloor (mbsf). Coring was terminated at $0045 \mathrm{~h}$ on 12 April 2011. Coring in Hole U1381B had two major objectives. The first objective was to establish a temperature gradient for the sediment section above oceanic crust. The second objective was to take samples for geochemistry and microbiology in the uppermost $30 \mathrm{~m}$ of sediment. Sediment Temperature Tool (SET) temperature measurements were taken at $~ 30,50,70$, and 90 mbsf. Overall core recovery for Site U1381 was $46.5 \%$. A total of 29 cores were recovered after coring $193.1 \mathrm{~m}$. The total length of core recovered at this site was $89.84 \mathrm{~m}$. Hole U1381B was terminated after drilled interval 334U1380B-43 after the last temperature measurement was made at $\sim 90$ mbsf.

\section{Hole U1381A}

Rig floor operations commenced at $2133 \mathrm{~h}$ on 8 April. The RCB BHA was made up with a Rock Bit International C-4 RCB bit and mechanical bit release. The trip to the seafloor was uneventful. The top drive was picked up, the drill string was spaced out, and the hole was spudded at $0330 \mathrm{~h}$ on 9 April. Coring continued for $69.25 \mathrm{~h}$ and was terminated after Core 334-U1381A-26R to move to Hole U1381B.

Total cored interval in Hole U1381A was $164.1 \mathrm{~m}$ with $73.86 \mathrm{~m}$ of core recovered for an RCB system recovery of $45.0 \%$. Last core on deck for Hole U1381A was at $0045 \mathrm{~h}$ on 12 April. The hole was displaced with $50 \mathrm{bbl}$ of $10.5 \mathrm{ppg}$ mud, and the drill string was pulled back to just above the seafloor with the top drive in place. The seafloor was cleared at $0220 \mathrm{~h}$, ending Hole U1381A.

\section{Hole U1381B}

After offsetting the vessel $20 \mathrm{~m}$ west, Hole U1381B was spudded at $0325 \mathrm{~h}$ on 12 April and advanced with the RCB coring system to 29.0 mbsf before running the SET. Three RCB cores were taken in Hole $\mathrm{U} 1381 \mathrm{~B}$ with a $15.98 \mathrm{~m}$ recovery. The cores were taken without circulation and were essentially punch cores. At 29.0 mbsf, the SET was run on wireline and the first measurement was taken. The hole was then advanced without recovery to 50 mbsf. The core barrel was pulled and the SET was again lowered by wireline to take the second measurement. The procedure was repeated for measurements at 71 and 91 mbsf. After the last temperature measurement was taken, the hole was displaced with 10.5 ppg heavy mud and the drill string was pulled back to surface. The rotary bit cleared the seafloor at $1440 \mathrm{~h}$ and cleared the rotary table at $1835 \mathrm{~h}$. The beacon was recovered at $1527 \mathrm{~h}$ and the rig was secured for transit at $1857 \mathrm{~h}$, ending Hole U1381B and Site U1381 on 12 April. The vessel left Site U1381 on a $100.6 \mathrm{nmi}$ transit to Puntarenas, Costa Rica, after completing operations during Expedition 334.

\section{Lithostratigraphy and petrology}

Site U1381 was drilled to investigate the lithostratigraphy of the sedimentary sequence on top of the Cocos Ridge as well as the uppermost portions of the Ridge to better characterize the material input into the subduction zone. Coring in a single hole from 0 to $165.04 \mathrm{mbsf}$ recovered sediment, sedimentary rocks, and igneous rocks.

The uppermost part of Hole U1381A is composed of a predominantly monotonous sequence of silty clay to clay. In the interval between Cores 334-U1381A- 
2R and 6R ( $\sim 3.5-50$ mbsf), a sequence of light greenish gray hemipelagic silicic ooze with terrigenous input is present. Three widely dispersed tephra horizons are recognized in a $14 \mathrm{~m}$ interval spanning from 34 to 48 mbsf. Below 51.1 mbsf (Cores 334U1381A-7R through 11R), a sequence of 26 tephra horizons is observed. This predominantly dark grayish to yellowish brown clayey unit is characterized by a greater abundance of calcareous ooze than the interval above 51.1 mbsf.

The contact between the basement and the overlying sediment was recovered in the lowermost segment of Section 334-U1381A-11R-CC at 95.44 mbsf. The actual contact is not preserved but is designated by the first occurrence of aphyric to phyric basalt. The lithostratigraphic record of the igneous units is incomplete because of lower recovery rates in Cores 334-U1381A-12R through 26R.

The igneous section (Unit III) consists predominantly of a sequence of fine- to coarse-grained pillow basalts. These pillow basalts are sometimes separated by a set of partly altered chilled margins and between 161.10-161.37 mbsf by a thin $(27 \mathrm{~cm})$ layer of volcaniclastics.

\section{Description of units}

The cores recovered from Hole U1381A (Cores 334U1381A-2R through 26R) can be divided into three lithostratigraphic units (Fig. F2). The $95.57 \mathrm{~m}$ cover sequence basement is divided into two units on the basis of lithologic attributes.

\section{Unit I}

Interval: 334-U1381A-2R-CC through 6R-CC

Thickness: $46.14 \mathrm{~m}$

Depth: 3.5-49.64 mbsf

Age: late Pleistocene to recent

Lithology: fine soft silty clay sediment

Unit I consists mainly of light greenish gray soft clay sediment with minor layers of silty clay and three tephra layers (Fig. F3). Tephra layers range from 2 to $4 \mathrm{~cm}$ thick, show gradation, and are partly disturbed and obscured by the rotary drilling process. In general, Unit I is massive with minor changes in the proportions of clay and silt. Biogenic components, especially nannofossils and diatoms, are abundant throughout the unit. Foraminifers, spicules, and radiolarians are present in trace abundances. Most of Unit I was intensely disrupted by RCB-related drilling disturbance. Silt-sized grains in smear slides include feldspar, chert, chlorite, pyroxene, amphibole, opaque minerals, calcite, glauconite, fragments of radiolarians, foraminifers, sponge spicules, glass, and rare quartz.

\section{Unit II}

Interval: 334-U1381A-7R through 11R-CC

Thickness: $49.64 \mathrm{~m}$

Depth: 49.64-95.57 mbsf

Age: Serravallian to Pleistocene

Lithology: silicic to calcareous ooze

Unit II consists mainly of dark grayish to yellowish brown, soft to hardened clay(stone) (Fig. F4). Toward the base, the sediment is partly silicified. Unit II is distinguished from Unit I by its abundant biogenic components, which is also reflected in the abrupt change in color. The sediment is $>70 \%$ spicules, diatoms, radiolarians, and nannofossils. With depth, the abundance of clay and the calcareous component increase within Unit II. Abundant tephra horizons, ranging from 1 to $8 \mathrm{~cm}$ thick, are massive and soft, show gradation, and are partly disturbed and smeared by rotary drilling. One notable exception is a $33 \mathrm{~cm}$ thick silicified mafic tephra layer in interval 334-U1381A-7R-1, $92 \mathrm{~cm}$, to 7R-2, $9 \mathrm{~cm}$, that shows parallel and cross lamination.

Biogenic components (sponge spicules, nannofossils, diatoms, and foraminifers) dominate the sediment. Serravallian age lithic (sediment $>$ magmatic) clasts and glass shards are still abundant in the silt to sand size of the detritus in the smear slides. Components present in trace abundances include feldspar, pyroxene, amphibole, calcite, and opaque minerals.

\section{Unit III}

Interval: $334-\mathrm{U} 1381 \mathrm{~A}-11 \mathrm{R}-\mathrm{CC}$ to $26 \mathrm{R}-3$

Thickness: $>69.6 \mathrm{~m}$

Depth: 95.44 to $>165.04$ mbsf

Lithology: pillow basalt

This unit consists mainly of pillow basalts of variable grain size, crystallinity, and vesicularity (see "Core descriptions") that are sometimes separated by chilled margins (Figs. F5, F6, F7, F8, F9). The basalt ranges from aphyric to sparsely or highly plagioclase-phyric or even glomerophyric. Plagioclase phenocrysts are euhedral to anhedral. Groundmass ranges from microcrystalline to fine- $(<0.5 \mathrm{~mm})$ or medium- $(0.5-1.0 \mathrm{~mm})$ grained, consisting of plagioclase and pyroxene. Vesicularity varies from almost nonvesicular to highly vesicular (>20\%; Fig. F6). Vesicles have round, elongate, and irregular shapes, especially those containing white to light green clay minerals, or the vesicles are spherical (preferentially filled with black to dark clay). Adjacent to chilled margins, the basalt is preferentially aphyric to sparsely plagioclase-phyric. The groundmass has the smallest grain size close to the chilled margins and becomes coarser farther away from the chilled margins. Chilled margins locally preserve glass; most of 
the glass is altered. The chilled margins including the glass at the contact and the altered basalt are of variable thickness and color. Chilled margins are 1 to $5 \mathrm{~cm}$ thick and range in color from dark gray or dark brown to lighter colors (Fig. F5).

\section{Tephra layers}

A total of 29 tephra layers are recognized in the core recovered at Hole U1381A. These tephra layers are intercalated with background Unit I (3 tephras) and Unit II (26 tephras) sediment. Individual tephra layers range in thickness from 1 to $33 \mathrm{~cm}$. Unconformable and/or inclined bedding is rare. In some cores, localized bioturbation is observed at the tops of the tephra layers. Some of the tephra layers have a sharp basal contact to underlying sediment and gradual transitional contact with overlying ash-bearing sediment and are well sorted. Drilling disturbance overprints the original structure of the tephra layers. As a result, we are unable to identify internal sedimentary structures within many of the tephra horizons. Some tephra layers are lithified (Fig. F10). Besides the greater abundance of tephra horizons in Unit II, no systematic features can be correlated with depth.

Compositions of the 29 identified tephra layers are variable. Of these 29 layers, 18 are pinkish gray/ brown and 11 are pinkish/greenish black. Dark black tephra beds account for $\sim 38 \%$ of the total tephra bed assemblage in Hole U1381A. The tephras in Unit I have similar mineral assemblages to those observed in Holes U1378B, U1379C, and U1380A. In contrast, the tephras in Unit II have generally lower crystal content than in Unit I and the sites arcward of the trench. In Unit II, the transparent glass shards of the more evolved tephras show no visible signs of alteration. Grain size ranges from medium to coarse ash (as large as millimeter size). The mineral assemblages consist of rare plagioclase and traces of pyroxene. Dark gray mafic ash layers consist predominantly of very coarse, dark to light brown sideromelane glass shards and rare tachylitic particles. Most of the sideromelane glass shards have blocky shapes and are medium to poorly vesicular but also show tubular-like glass shards. The glass shards are well preserved without obvious alteration features. The mineral assemblages of the mafic tephras include rare plagioclase and trace pyroxene.

\section{Depositional environment and correlation to Sites U1378 and U1379}

The cover sequence recovered from Hole U1381A consists of a sequence of hemipelagic siliceous ooze with terrigenous input, presumably remobilized from the slope sediment sequence, overlying pelagic calcareous ooze (see also "Paleontology and biostratigraphy").

\section{Alteration}

Alteration of basalt in Hole U1381A occurs along vesicles and veins, as well as in matrix, forming rims, bands, or networks of alteration zones. The vesicles are filled with green clay, sometimes with zeolite in the center, and accompanying aggregates of pyrite. The surrounding glass is altered to narrow (0.1-0.3 $\mathrm{mm}$ ) black rims around the vesicles composed of iron oxyhydroxides and dark gray clay. Most of the veins are composed of green clay with minor amounts of calcite and pyrite aggregates. The vein wall and rims are altered to black. Apart from vesicles and veins, black alteration zones form irregular straight bands or irregular spots. In these black alteration zones, glass is completely altered, whereas groundmass plagioclase tends to survive. Some of plagioclase phenocrysts in these alteration zones are altered completely to green clay, forming green spots. In general, the intensity of alteration generally increases with depth.

\section{Paleontology and biostratigraphy}

At Site U1381, core catcher samples from sedimentary layers in the upper part of Hole U1381A were analyzed for calcareous nannofossils and foraminifers. The calcareous nannofossils observed at this site provided a significant biostratigraphic control of the cored sediment sequence above the basalts of the Cocos Ridge. Based on microfossil biostratigraphy, the sedimentary layers are tentatively divided into an upper part, of Pleistocene age, and a lower part, of middle Miocene age. Thus, the sediments just above the basalts are tentatively estimated to be of middle Miocene age and younger than $16 \mathrm{Ma}$. The zonation of planktonic foraminifers is approximately concordant with that of the calcareous nannofossils.

Diverse calcareous nannofossil assemblages ranging from the Pleistocene to the lower middle Miocene are present in Samples 334-U1381A-2R-CC (3.69 mbsf) through 11R-CC (95.5 mbsf). Two different environments are represented in this section by nannofossil abundance and preservation. The upper interval, spanning from Sample 2R-CC (3.69 mbsf) through 6R-CC (49.62 mbsf), represents a hemipelagic environment mixed with terrigenous material. The lower interval, a silicic to calcareous ooze spanning from Sample 7R-CC (53.86 mbsf) through Sample 11R-CC (95.5 mbsf), represents a pelagic environment. The presence, abundance, and preservation of 
the calcareous nannofossils recovered from Hole U1381A are reported in a range distribution chart (Table T2).

Samples 334-U1381A-2R-CC through 4R-CC cannot be biostratigraphically zoned because of poor preservation and the lack of zonal markers. Though undetermined, the assemblages are characteristic of the lower Pleistocene Zones NN20-NN19 and contain Gephryocapsa oceanica, Gephryocapsa caribbeanica, Helicosphaera carteri, and Calcidiscus leptoporus.

Sample 334-U1381A-5R-CC (49.52 mbsf) is tentatively assigned to nannofossil Zone NN19 based on the occurrence of Pseudoemiliania lacunosa and the absence of Discoaster brouweri. However, the top boundary, defined by the last occurrence of $P$. lacunosa, is undetermined.

Sample 334-1381A-6R-CC (49.62 mbsf) contains a diverse nannofossil assemblage of mixed ages, ranging from Pleistocene Zone NN19 into the lower to middle Miocene. The discoasters are poorly to moderately preserved, whereas the placoliths exhibit moderate to good preservation. The condition of the discoasters and the rarity or lack of biostratigraphic markers prevents the further delineation of the Pliocene and Miocene zones. The diverse assemblage is dominated by Pleistocene species, including G. oceanica, G. caribbeanica, H. carteri, and C. leptoporus. Also present, but rare to a few in abundance, are Miocene species including Discoaster bellus, Discoaster exilis, Discoaster quinqueramus, Discoaster variabilis, and unidentifiable five- and six-rayed discoasters.

Samples 334-U1381A-7R-CC (53.86 mbsf) through 11R-CC (95.5 mbsf) are assigned to middle Miocene Zone NN5 based on the occurrence of Helicosphaera heteromorphus and the absence of Helicosphaera ampliaperta. The top and bottom of this zone cannot be constrained because of the uncertainty of the last occurrences of the biostratigraphic markers. Typical species found in the samples include Sphenolithus heteromorphus, Sphenolithus moriformis, C. leptoporus, Cyclicargolithus floridanus, Coccolithus miopelagicus, D. exilis, D. variabilis, Discoaster deflandrei, and Reticulofenestra pseudoumbilicus.

\section{Foraminifers}

Planktonic foraminifers were analyzed in nine core catcher samples (Table T3). Foraminifers are abundant to common in the sediment of Hole U1381A. Preservation is good to moderate. Fragmentation of foraminifers caused by carbonate dissolution is observed in the samples of sediment from lower bathyal depths. Planktonic foraminifers, abundant to common in this hole, are much more abundant than benthic foraminifers. These trends are different from the trends observed in the cored sediment of the other sites. Similar to the observed nannofossil communities in this hole, the foraminiferal assemblages of the uppermost part of the sediment sequence are quite different from those of the lower parts. This is either caused by a hiatus or by very low sedimentation rates. The upper sediment sequence (3.69-49.62 mbsf) contains a foraminiferal community characteristic of a tropical fauna (Globigerinoides quadrilobatus [Globigerinoides sacculifer], Globigerinoides ruber, Orbulina universa, Globorotalia menardii, and Neogloboquadrina dutertrei). Sample 334-U1381A-3RCC (13.34 mbsf) contains pink G. ruber and is assigned to the Pleistocene (older than 0.12 Ma). Sample 6R-CC contains sinistrally coiling Pulletiatina and is older than $0.8 \mathrm{Ma}$ but younger than $6.4 \mathrm{Ma}$. From 53.86 (Sample 7R-CC) to 95.55 mbsf (Sample 10RCC) the planktonic foraminiferal assemblages are composed of Dentoglobigerina altispira, G. quadrilobatus, Globigerinoides obliquus, Globoquadrina dehiscens, Globorotalia peripheroronda, Globorotalia peripheroacuta, Paragloborotalia siakensis, and Orbulina suturalis. This sequence is tentatively assigned to planktonic foraminiferal Zone M7 (14 Ma). However, the occurrence of Praeorbulina circularis in Sample 10RCC (95.55mbsf) may be a sign that the sediments just above the basement basalt are much older (either M5 or M6).

\section{Structural geology}

The main structural geology goal during Expedition 334 was to describe and document style, geometry, and kinematics of structural features observed in the cores. At Site U1381, cores from the sedimentary sequence $(\sim 95 \mathrm{~m})$ and the underlying oceanic basement basalt of the Cocos plate were retrieved. Gently dipping (mostly $<15^{\circ}$ ) bedding is the only structure observed in the cores retrieved from the sedimentary sequence. The basement basalt contains fractures, some of which are filled with vein minerals. The dip angle of the fractures and of the veins shows a scattered distribution from $>0^{\circ}$ to $86^{\circ}$ (Fig. F11).

\section{Structures in sediment}

Bedding dips were the only structures observed in the sediment cores retrieved at Site U1381. No brittle deformation such as faults or fractures was recognized in the sediment cores. Bedding planes were recognized as boundaries between different sediment compositions or grain sizes. Bedding in the sediments at Site U1381 dips gently $\left(<15^{\circ}\right)$, as shown in Figure F11. 


\section{Structures in basalt}

Many fractures and mineral-filled veins (mostly calcite) were identified in the basement basalt (Fig. F12). The population frequency of the fractures was estimated as $<10$ fractures $/ 10 \mathrm{~m}$ in the uppermost part of the basalt sequence (95-140 mbsf) and $>10$ fractures/10 $\mathrm{m}$ in the lowermost part (140-164 mbsf). It appears that the density of the veins increases downhole (Fig. F11). Some of the fractures exhibit an alteration zone filled with greenish clay minerals and pyrite (Fig. F12; see "Lithostratigraphy and petrology" for a detailed description). Vein thicknesses are mostly $<1 \mathrm{~mm}$. The dip angle of the fractures shows a scattered distribution from $0^{\circ}$ to $86^{\circ}$ (Fig. F11). Sedimentary sequences interbedded in the basement basalt have bedding planes with gentle $\operatorname{dips}\left(<20^{\circ}\right)$.

\section{Geochemistry and microbiology Geochemistry}

We collected 12 whole-round samples from Hole U1381A for pore fluid analysis at a frequency of one or two samples per core, depending on recovery. All the samples were exposed to the atmosphere prior to squeezing. Hole U1381A was cored by RCB, with no recovery in the uppermost $13 \mathrm{~m}$ of the sediment column. The first whole round was collected from Core 334-U1381A-3R. To acquire pore fluids from the uppermost $13 \mathrm{~m}$ at this site, two cores were collected in Hole U1381B by "punching" the sediment with the RCB system, much like a piston core. To connect with the previous profile, a third core was collected by RCB. We sampled three whole rounds from the first core in Hole U1381B and one whole round each in the second and third cores. Because of time constraints, we focused our efforts on collecting samples for postcruise studies in Hole U1381B and only a limited number of analyses were carried out on board.

No gas samples were collected in Hole U1381B. Nine headspace (HS) samples were collected for safety monitoring in Hole U1381A and analyzed on the gas chromatograph-flame ionization detector on the natural gas analyzer (NGA). Methane concentrations were at background concentrations at Site U1381, and ethane and higher hydrocarbons were not detected. Thus, the organic geochemistry at this site is not reported in the data tables. The inorganic geochemistry data are listed in Table T4 and plotted in Figure F13.

From 13 to 24 mbsf, salinity is lower than the seawater value (35) and increases to 34 at the base of the hole. Chloride concentrations are slightly below the modern seawater value $(559 \mathrm{mM})$ through the cored section, averaging $554 \mathrm{mM}$ with a minimum concentration of $550 \mathrm{mM}(\sim 1.5 \%$ lower than seawater). A similar dilution of $\mathrm{Cl}$ concentrations of $\sim 2.5 \%$ lower than modern seawater was observed in the uppermost $100 \mathrm{~m}$ of the sediment column cored at the reference site (ODP Site 1039) offshore the Nicoya Peninsula (Kimura, Silver, Blum, et al., 1997). Sodium concentrations are also below the seawater value throughout the cored section and reach a minimum of $437 \mathrm{mM}$ at 35 mbsf. Sodium concentrations are relatively constant below this depth, averaging $\sim 465 \mathrm{mM}$.

Sulfate concentrations decrease from $15 \mathrm{mM}$ at 13 mbsf to a minimum of $11 \mathrm{mM}$ at 23 mbsf. Sulfate concentrations then increase nearly linearly with depth to $24 \mathrm{mM}$ at the sediment/basement interface. The return to seawater-like values below 23 mbsf in the sulfate profile indicates lateral flow of altered seawater in the basement at this site. The diffusion of sulfate from this basement fluid to the sediment column and from the overlying water column must be faster than the rates of microbial sulfate reduction, keeping sulfate from reaching depletion in the reference section. This trend was also observed in the reference sediment column offshore Nicoya Peninsula (Kimura, Silver, Blum, et al., 1997). The alkalinity concentration-depth profile is a mirror image of the sulfate profile, reaching a maximum of $17.7 \mathrm{mM}$ at 23 mbsf and decreasing to $4 \mathrm{mM}$ at the base of the hole. Organic matter diagenesis in the uppermost part of the sediment section is also observed in the ammonium profile, which reaches a maximum value of $1.45 \mathrm{mM}$ at 23 mbsf. Ammonium concentrations remain nearly constant to $35 \mathrm{mbsf}$ and decrease nearly linearly to $0.42 \mathrm{mM}$ at the base of the hole. Calcium concentrations reach a minimum value of $4.8 \mathrm{mM}$ just below the sulfate minimum at $23 \mathrm{mbsf}$, suggesting precipitation of authigenic carbonates in the zone of active sulfate reduction and alkalinity production. Below this depth, Ca concentrations increase to $13.5 \mathrm{mM}$ at the base of the hole. The increase in Ca with depth likely reflects both ash alteration in the sediment column and diffusional communication with the basement fluid.

Potassium concentrations decrease gradually with depth, reaching minimum values at the base of the hole. Magnesium concentrations decrease to $35 \mathrm{mM}$ at 35 mbsf, suggesting volcanic ash alteration within a depth interval consisting of abundant tephra layers (34-48 mbsf) (see "Lithostratigraphy and petrology"). Magnesium concentrations remain relatively constant between 45 and 81 mbsf and decrease to 46 $\mathrm{mM}$ at the sediment/basement interface. In summary, the pore fluid profiles in the uppermost $\sim 40 \mathrm{~m}$ 
of the sediment section at this site reflect reactions related to organic carbon cycling as well as volcanic ash alteration, and, to a lesser extent, clay-ion exchange reactions. The pore fluid profiles of $\mathrm{SO}_{4}$, alkalinity, $\mathrm{Ca}$, and $\mathrm{Mg}$ below this depth reflect ongoing ash alteration and ion exchange reactions with the sediment column and diffusional communication with a basement fluid. The estimated composition of this fluid $\left(\mathrm{Ca}=\sim 13 \mathrm{mM}, \mathrm{Mg}=\sim 46 \mathrm{mM}\right.$, and $\mathrm{SO}_{4}=$ $\sim 24 \mathrm{mM}$ ) suggests that it is likely seawater that is only moderately modified by reaction with basalt along the fluid flow path.

\section{Microbiology}

Microbiological sampling consisted of $5 \mathrm{~cm}$ wholeround samples cut on the catwalk and subsampled in the laboratory using sterile techniques. In Hole U1381A, which was all RCB coring in soft sediment, one whole-round sample was taken in each of Cores 334-U1381A-5R through 9R and 11R. The choice of cores was guided by core recovery. Whole-round samples were not taken once basement was reached. In Hole U1381B, three whole-round samples were taken in Core 334-U1381B-1R, and one sample was collected in Cores 2R and 3R. Subsampling of the whole-round samples was performed for three different categories of research endeavors: (1) frozen samples for molecular analyses, (2) refrigerated samples for cultivation studies, and (3) paraformaldehydefixed samples for cell counting and contamination testing.

Fixed samples for cell counting were further prepared on board with a SYBR Green I staining procedure; however, because of the short time remaining, enumeration estimates will be performed postcruise along with the other analyses. No microspheres were deployed during RCB coring because of potential damage to the soft sediments from the microsphere bags.

\section{Physical properties}

At Site U1381, physical properties measurements were made to provide basic information characterizing lithostratigraphic units. After sediment cores reached thermal equilibrium with ambient temperature at $\sim 20^{\circ} \mathrm{C}$, gamma ray attenuation (GRA) density, magnetic susceptibility, and $P$-wave velocity were measured using the Whole-Round Multisensor Logger (WRMSL). For basement cores, only GRA density and magnetic susceptibility were measured. After WRMSL scanning, the whole-round sections were logged for natural gamma radiation (NGR). Thermal conductivity was measured using the full-space method on sediment cores and the half-space method on split basement cores. A photo-image-capture logger and color spectrophotometer were used to collect images of the split surfaces of the archivehalf cores on the Section Half Image Logger and Section Half Multisensor Logger (SHMSL), respectively. Discrete $P$-wave measurements were made on split sediment cores. Moisture and density (MAD) were measured on discrete subsamples collected from the working halves of the split sediment cores. MAD was not measured on basement cores because of time limitations.

\section{Density and porosity}

Bulk density values at Site U1381 were determined from both GRA measurements on whole cores and mass/volume measurements on discrete samples from the working halves of split cores (see "Physical properties" in the "Methods" chapter [Expedition 334 Scientists, 2012]). A total of 25 discrete samples were analyzed for MAD.

In general, wet bulk density values determined from whole-round GRA measurements and measurements from discrete samples agree well (Fig. F14A). Gaps in the measurements are due to incomplete core recovery with the RCB system. Wet bulk density values within the sedimentary sequence have an average and standard deviation of 1.40 and $0.14 \mathrm{~g} / \mathrm{cm}^{3}$, respectively. Within the basement, GRA-derived bulk densities are highly scattered because of the variable filling of the core liner. Within basement, maximum bulk density values are $\sim 2.3 \mathrm{~g} / \mathrm{cm}^{3}$.

Grain density measurements were determined from mass/volume measurements on discrete samples within the sedimentary sequence. Although scatter in grain density values are high, grain densities generally decrease with depth from $\sim 2.7$ to $2.5 \mathrm{~g} / \mathrm{cm}^{3}$ (Fig. F14B).

Porosity was determined from mass/volume measurements on discrete samples using MAD Method C on sediment cores (see "Physical properties" in the "Methods" chapter [Expedition 334 Scientists, 2012]). Porosity is relatively constant with depth, with a mean value of $76 \%$ (Fig. F14C). In general, porosity is expected to decrease with depth. The constant values may reflect disturbances caused by RCB coring. A low porosity value, caused by silicification, was measured at 52 mbsf in an ash layer (see "Lithostratigraphy and petrology").

\section{Magnetic susceptibility}

Volumetric magnetic susceptibilities were measured using the WRMSL, and point measurements were made on the SHMSL for all recovered cores from Site U1381. Uncorrected values of magnetic susceptibil- 
ity are presented in Figure F15. Magnetic susceptibility values measured with these two methods are in good agreement. In the sediment, mean magnetic susceptibility was low, with a mean and standard deviation of 0.009 and 0.016 SI, respectively.

Within basement, values increased from the sediment/basement interface to $140 \mathrm{mbsf}$ and slowly decreased to the bottom of the hole (Fig. F15). Maximum values of magnetic susceptibility varied between 1 and 2 SI.

\section{Natural gamma radiation}

NGR results are reported in counts per second (cps; Fig. F16). NGR counting intervals in the sediments were $\sim 10$ min per whole-core interval, and NGR counts are considered reliable. Basement counting times were $1 \mathrm{~h}$ per channel. In the shallow part of the basement, 12 channels were used, but in the deeper basement only six channels were used because of time constraints.

NGR counts within the sediment vary between $\sim 10$ and 30 cps, with maximum values occurring at $\sim 30$ mbsf. NGR counts within the basement are generally $<5 \mathrm{cps}$ and increase slightly with depth.

\section{P-wave velocity}

Measurements of $P$-wave velocity at Site U1381 were determined from measurements on sediment whole cores and mass/volume measurements on discrete samples from the working halves of sediment and basement split cores (see "Physical properties" in the "Methods" chapter [Expedition 334 Scientists, 2012]). In general, whole-core and discrete measurements on sediments are in good agreement (Fig. F17). The mean value is $1558 \mathrm{~m} / \mathrm{s}$, close to the compressional velocity of water.

\section{Thermal conductivity}

Thermal conductivity measurements were conducted on sediment whole-round cores using the needle-probe method and on basement split cores using the half-space method (see "Physical properties" in the "Methods" chapter [Expedition 334 Scientists, 2012]). The mean and standard deviation in sediment thermal conductivity measurements are 0.80 and $0.07 \mathrm{~W} /(\mathrm{m} \cdot \mathrm{K})$, respectively (Fig. F18A).

The mean and standard deviation of thermal conductivity in the basalt is 1.45 and $0.07 \mathrm{~W} /(\mathrm{m} \cdot \mathrm{K})$, respectively. These values are low for basalt and can be attributed to the fact that the samples were not water saturated before measurement because of time constraints.

\section{Downhole temperature}

Downhole temperature was measured using the SET. The advanced piston corer temperature tool is not compatible with the RCB coring system and was not used. Four measurements were attempted between 30 and 90 mbsf in Hole U1381B. All measurements were made in sediment.

All measurements were made in a low sea state $(<1 \mathrm{~m}$ swell), and all temperature-time series were recorded with a sample interval of $1 \mathrm{~s}$. The SET was stopped at the mudline for as long as $10 \mathrm{~min}$ prior to each penetration. The average bottom water temperature was $2.4^{\circ} \mathrm{C}$ (Table T5). Temperature-time series for each temperature measurement are shown in Figure F19.

Significant frictional heating occurred only on penetration 3 of the SET, with the temperature-time record exhibiting characteristic probe penetration and subsequent decay. Tool movement was observed in all temperature records as sudden shifts in temperature both before and after the usable section of the temperature-time series. Tool movement is attributed to using the SET in high-porosity unlithified sediments. The effective origin time of the frictional heat pulse was estimated by varying the assumed origin time until the thermal decay pulse best fit a theoretical curve. As a result, tool movement fits to the equilibrium curve are relatively short (Table T5). Nevertheless, the measurements appear to be reliable and are likely good to a few tenths of a degree Celsius. Equilibrium temperatures plotted as a function of depth are relatively linear; coupled with the average bottom water temperature, they give a leastsquares gradient of $222^{\circ} \mathrm{C} / \mathrm{km}$ (Fig. F18B).

\section{Heat flow}

Because thermal conductivity appears relatively constant and the thermal gradient is linear, we compute heat flow as the product of the thermal conductivity and thermal gradient. Using the mean thermal conductivity of $0.8 \mathrm{~W} /(\mathrm{m} \cdot \mathrm{K})$ gives a heat flow of 178 $\mathrm{mW} / \mathrm{m}^{2}$. This value is significantly larger than the half-space prediction for $15 \mathrm{Ma}$ crust of $\sim 130 \mathrm{~mW} / \mathrm{m}^{2}$ and much larger than the observed global average heat flow for this age crust of $77 \mathrm{~mW} / \mathrm{m}^{2}$ (Stein and Stein, 1992). This high heat flow value suggests significant fluid flow within the underlying crust.

\section{Vane shear}

Undrained shear strengths increase with depth (Fig. F20). The trend is approximately linear in the uppermost 40 mbsf, with a maximum value of 40 $\mathrm{kPa}$. Values decrease and display more erratic behavior downhole. This change may correspond to 
a change in lithostratigraphy (see "Lithology and petrology").

\section{Color spectrometry}

Results from color reflectance measurements are presented in Figure F21. In the sediment sequence, $L^{*}$ values vary between $\sim 35$ and 50 and vary in the basement between 10 and 50 . Variability in $\mathrm{a}^{*}$ decreases with depth through the sediment section and are between approximately -3 and 2 . Mean basement values of $a^{*}$ vary between about -2 and 1 . Mean $b^{*}$ values appear inversely correlated to $a^{*}$ and vary between -5 and 10 in the sediment and -5 and 0 in the basement.

\section{Paleomagnetism}

We made pass-through magnetometer measurements on all archive-half cores and on discrete samples taken from the working halves recovered in Hole U1381A. Sedimentary archive-half cores were demagnetized in an alternating field (AF) up to 30 $\mathrm{mT}$ and measured with the pass-through superconducting rock magnetometer (SRM) at $5 \mathrm{~cm}$ intervals. Basalt basement split cores were demagnetized up to $10 \mathrm{mT}$ and measured at $2 \mathrm{~cm}$ intervals. Paleomagnetic discrete samples were subjected to stepwise AF demagnetization and measured in both the SRM and JR6 magnetometer. Several discrete samples were also subjected to stepwise thermal demagnetization to $600^{\circ} \mathrm{C}$. No single shipboard paleomagnetic discrete sample was taken from basement Cores 334U1381A-16R through 26R because of time constraints for the final operation of the expedition. All archive-half sections from Hole U1381B were measured with the pass-through SRM at $5 \mathrm{~cm}$ intervals and AF demagnetized up to $20 \mathrm{mT}$. Both normal and reversed polarities were observed, but no further data analyses could be performed.

\section{Natural remanent magnetization}

\section{Sedimentary cores}

The uppermost $97 \mathrm{~m}$ of Hole U1381A consists of a sequence of yellow to green-gray silty clay. Natural remanent magnetization (NRM) of these sediments shows similar characteristics as those at Site U1380. Steep downward drilling-induced remagnetization exists in the recovered cores (Fig. F22), as evidenced by dominantly positive inclinations (mean $\sim 45^{\circ}$ ), which is steeper than the inclinations expected for the latitude of the site $\left(\sim 17^{\circ}\right)$. NRM has no preferred declinations (Fig. F22A), suggesting that the radialinward remagnetization observed at Site U1379 is less severe in Hole U1381A. The mean NRM inten- sity for the sedimentary interval is $\sim 10^{-3} \mathrm{~A} / \mathrm{m}$ and slightly decreases downhole. Between $\sim 30$ and 35 mbsf (Core 334-U1381A-4R), higher NRM intensity values are apparent.

\section{Basement rocks}

The lowermost $\sim 70 \mathrm{~m}$ of Hole U1381A consists mainly of basaltic rocks. We selected pieces longer than $\sim 5 \mathrm{~cm}$ in the archive halves for the passthrough measurements with an interval of $2 \mathrm{~cm}$ (Fig. F23). Measured declination and inclination are consistent within each coherent piece. NRM declination has no preferred direction, and inclination ranges from approximately $-45^{\circ}$ to approximately $+45^{\circ}$. $\mathrm{NRM}$ intensity scatters from $\sim 1$ to $8 \mathrm{~A} / \mathrm{m}$. It appears that NRM inclination and intensity vary downhole and can be correlated to the alteration states of the rocks. The relatively fresh samples from the top of the basalt section (Cores 334-U1381A-12R to 16R) frequently show inclinations consistent with the low latitude of the site, indicating that the drilling-induced vertical remagnetization in the basaltic cores is much less severe than in the sediments drilled during this expedition. The fresh part of the basalt is also characterized by stronger NRM intensity. Below this fresh part in Cores 334-U1381A-19R to 26R, samples are relatively altered and show lower NRM intensity with inclinations of $\sim 50^{\circ}$, indicating more contamination from the drilling-induced remagnetization compared with the relatively fresh part. The majority of the measured basaltic pieces have positive inclinations, but several pieces also exhibit negative inclinations (Fig. F23), possibly reflecting prolonged igneous activities at the site.

\section{Demagnetization behavior}

\section{Sedimentary cores}

Because of the relatively deep water and slower drilling rate for coring basement rocks, we had time to perform more detailed AF demagnetization on the archive halves. For the recovered sediment core sections, we employed AF demagnetization steps up to $30 \mathrm{mT}$ with $5 \mathrm{mT}$ increments. AF demagnetization with 5-10 $\mathrm{mT}$ seems to be effective in removing the drilling-induced remagnetization, as shown by inclinations shifted toward shallower values comparable to the expectation for the site. A factor of $3 \sim 4$ decrease in magnetization intensity after $5 \mathrm{mT}$ demagnetization and one order of magnitude decrease after $30 \mathrm{mT}$ demagnetization are evident suggesting the magnetization is dominated by a low-coercivity and low-stability component (Fig. F22C).

Interestingly, inclinations from Cores 334-U1381A$5 \mathrm{R}$ through $6 \mathrm{R}$ at $\sim 40-50 \mathrm{mbsf}$ moved from positive 
to negative values after progressive AF demagnetization. After $30 \mathrm{mT}$ AF demagnetization, the inclinations for these two cores scatter around a mean of $45^{\circ}$ (Fig. F22C). Although biostratigraphic evidence suggests that cores below Core 6R may have a middle Miocene age (see "Paleontology and biostratigraphy"), we suspect this negative inclination behavior is an experimental artifact based on the following observations:

- A strong anhysteric remanent magnetization (ARM) effect that shows bias toward negative inclination was noticed during our test runs for $\mathrm{AF}$ field $>40 \mathrm{mT}$ by the SRM in-line demagnetizer (see "Paleomagnetism" in the "Methods" chapter [Expedition 334 Scientists, 2012]),

- The negative inclination value is scattered and steeper than the expected dipole field value $\left(-17^{\circ}\right)$ for the site, and

- Some discrete samples also show similar negative inclination values during AF demagnetization with the in-line demagnetizer after $30 \mathrm{mT} \mathrm{AF}$ demagnetization, suggesting the existence of the ARM effect.

Thus, we do not interpret the inclination behavior of the archive halves to be records of reversed polarity of magnetization. Shore-based AF and thermal demagnetization work is needed to check this interpretation.

As shown in Figure F24, AF demagnetization on discrete samples can isolate characteristic remanent magnetization (ChRM) after the removal of the overprints. However, at high demagnetization levels on the SRM in-line demagnetizer, discrete samples frequently show bias toward negative values. In addition, several samples from the lowermost part of the sedimentary sequence have remanence intensity that is too weak $\left(<10^{-4} \mathrm{~A} / \mathrm{m}\right)$ for the shipboard experiments to determine ChRM reliably (e.g., Fig. F25C). Establishment of the magnetic polarity stratigraphy for Site U1381 must wait for shore-based studies that can utilize more sensitive instrumentation and reliably measure the weak magnetization.

\section{Basement rocks}

Based on the pilot results of AF demagnetization measurements on Section 334-U1381A-12R-1 up to $15 \mathrm{mT}$, we performed AF demagnetization at steps 5 and $10 \mathrm{mT}$ for the rest of the archive halves. Generally speaking, both intensity and direction of NRM show only little change after the $5 \mathrm{mT}$ demagnetization. After $10 \mathrm{mT}$ AF demagnetization, remanence intensity decreased by a factor of $\sim 2(\sim 1-4 \mathrm{~A} / \mathrm{m})$. Direction of NRM shows little change, even after the 10 mT step (Fig. F23).
AF demagnetization of discrete samples revealed behaviors similar to the archive halves. The discrete samples show well-defined ChRM with only slight signs of overprint at the lowest demagnetization steps (Fig. F25). AF demagnetization was very effective, and median destructive fields are between 5 and $10 \mathrm{mT}$ (Fig. F26). These samples revealed inclinations consistent with the SRM measurements of the corresponding long core pieces in the archive halves, including one with negative inclination (Figs. F23, F25).

We also performed thermal demagnetization on discrete samples. Paleomagnetic minicore $\left(10 \mathrm{~cm}^{3}\right)$ samples were treated using the TSD-1 thermal demagnetizer from $100^{\circ}$ to $550^{\circ} \mathrm{C}$ at $25^{\circ} \mathrm{C}$ increments, then at $580^{\circ}$ and $600^{\circ} \mathrm{C}$. Increments of $50^{\circ} \mathrm{C}$ were used between $300^{\circ}$ and $450^{\circ} \mathrm{C}$. Magnetization was measured using the JR-6 magnetometer. Magnetization decreases by $\sim 40 \%$ after heating to $100^{\circ} \mathrm{C}$ and then remains stable up to $\sim 250^{\circ} \mathrm{C}$. Two samples show slight increases in magnetization between $250^{\circ}$ and $300^{\circ} \mathrm{C}$. After $300^{\circ} \mathrm{C}$, all samples show a steady decrease of magnetization. Most of the remanence has unblocked by $525^{\circ} \mathrm{C}$, and demagnetization was completed by $580^{\circ} \mathrm{C}$ (Fig. F27). Magnetization directions are stable throughout thermal demagnetization experiment, with minor indications of vertical component demagnetization during low-temperature heating steps (Fig. F25). The unblocking temperature indicates that titanomagnetite with low Ti content is the most likely NRM carrier. The components demagnetized by the $100^{\circ} \mathrm{C}$ heating step most likely represent a viscous remanence overprint. The increase in magnetization at $\sim 275^{\circ} \mathrm{C}$ may result from oxidation of (titano)maghemite. All examined samples revealed positive inclination, consistent with the SRM measurements on the corresponding long pieces from the archive halves.

\section{References}

Barckhausen, U., Ranero, C.R., von Huene, R., Cande, S.C., and Roeser, H.A., 2001. Revised tectonic boundaries in the Cocos plate off Costa Rica: implications for the segmentation of the convergent margin and for plate tectonic models. J. Geophys. Res., [Solid Earth], 106(B9):19207-19220. doi:10.1029/2001JB000238

Expedition 334 Scientists, 2012. Methods. In Vannucchi, P., Ujiie, K., Stroncik, N., Malinverno, A., and the Expedition 334 Scientists, Proc. IODP, 334: Tokyo (Integrated Ocean Drilling Program Management International, Inc.). doi:10.2204/iodp.proc.334.102.2012

Fisher, A.T., Stein, C.A., Harris, R.N., Wang, K., Silver, E.A., Pfender, M., Hutnak, M., Cherkaoui, A., Bodzin, R., and Villinger, H., 2003. Abrupt thermal transition reveals hydrothermal boundary and role of seamounts within 
the Cocos plate. Geophys. Res. Lett., 30(11):1550-1553. doi:10.1029/2002GL016766

Kimura, G., Silver, E.A., Blum, P., et al., 1997. Proc. ODP, Init. Repts., 170: College Station, TX (Ocean Drilling Program). doi:10.2973/odp.proc.ir.170.1997

Morris, J.D., Villinger, H.W., and Klaus, A. (Eds.), 2006. Proc. ODP, Sci. Results, 205: College Station, TX (Ocean Drilling Program). doi:10.2973/odp.proc.sr.205.2006

Silver, E., Kastner, M., Fisher, A., Morris, J., McIntosh, K., and Saffer, D., 2000. Fluid flow paths in the Middle America Trench and Costa Rica margin. Geology, 28(8):679-682. doi:10.1130/00917613(2000)28<679:FFPITM>2.0.CO;2

Stein, C.A., and Stein, S., 1994. Constraints on hydrothermal heat flux through the oceanic lithosphere from global heat flow. J. Geophys. Res., [Solid Earth], 99(B2):3081-3095. doi:10.1029/93JB02222

von Huene, R., Ranero, C.R., Weinrebe, W., and Hinz, K., 2000. Quaternary convergent margin tectonics of Costa Rica, segmentation of the Cocos plate, and Central American volcanism. Tectonics, 19(2):314-334. doi:10.1029/1999TC001143

Zijderveld, J.D.A., 1967. AC demagnetization of rocks: analysis of results. In Collinson, D.W., Creer, K.M., and Runcorn, S.K. (Eds.), Methods in Palaeomagnetism: New York (Elsevier), 254-286.

Publication: 12 April 2012 MS 334-106 
Figure F1. Detail of poststack time-migrated Seismic BGR99 Line 7 centered at Site U1381. CMP = common midpoint.

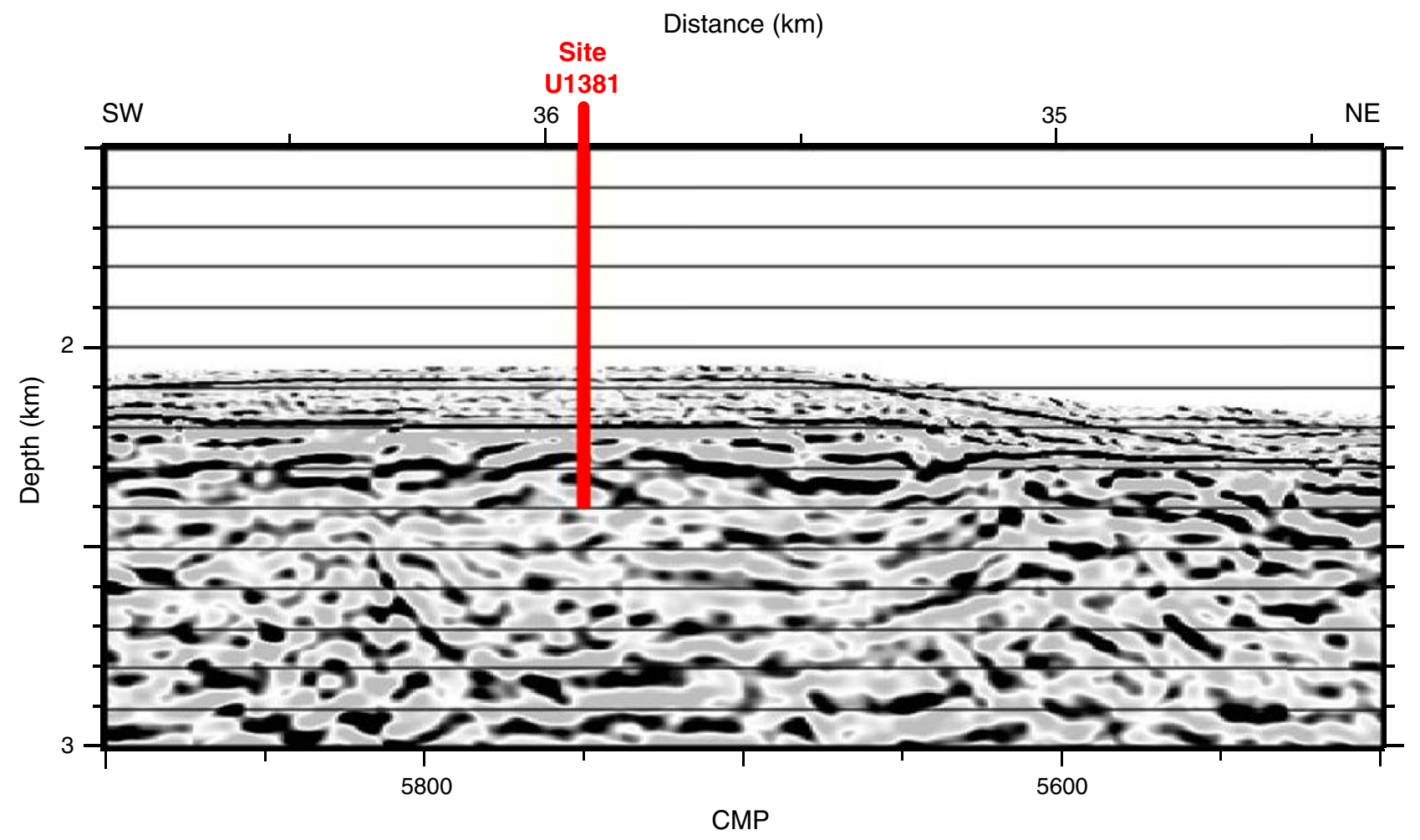


Figure F2. Graphic summary log, Hole U1381A.

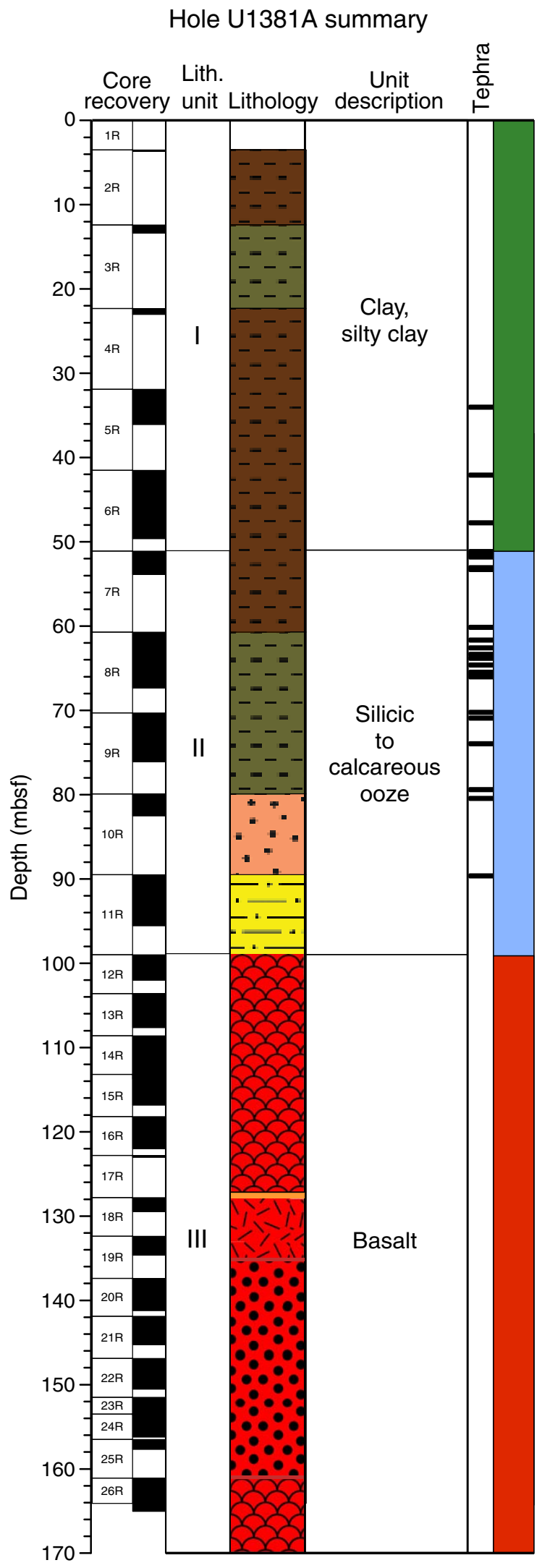


Figure F3. Representative core image of Unit I with typical homogeneous light greenish gray silty clay with disturbed lenses of a former tephra layer (interval 334-U1381A-6R-5, 1-26 cm).

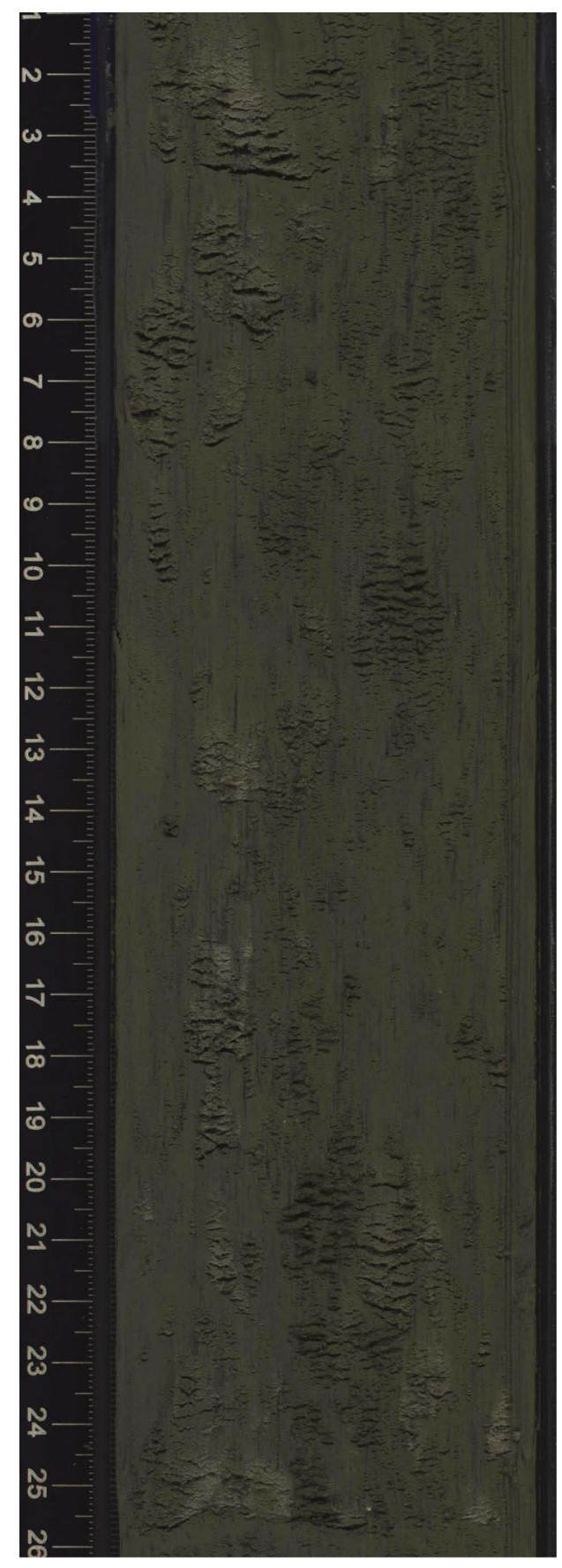


Figure F4. Representative core image of Unit II with typical dark grayish to yellowish brown silty clay with a black tephra layer between 35 and $37 \mathrm{~cm}$ (interval 334-U1381A-7R-3, 27-39 cm).

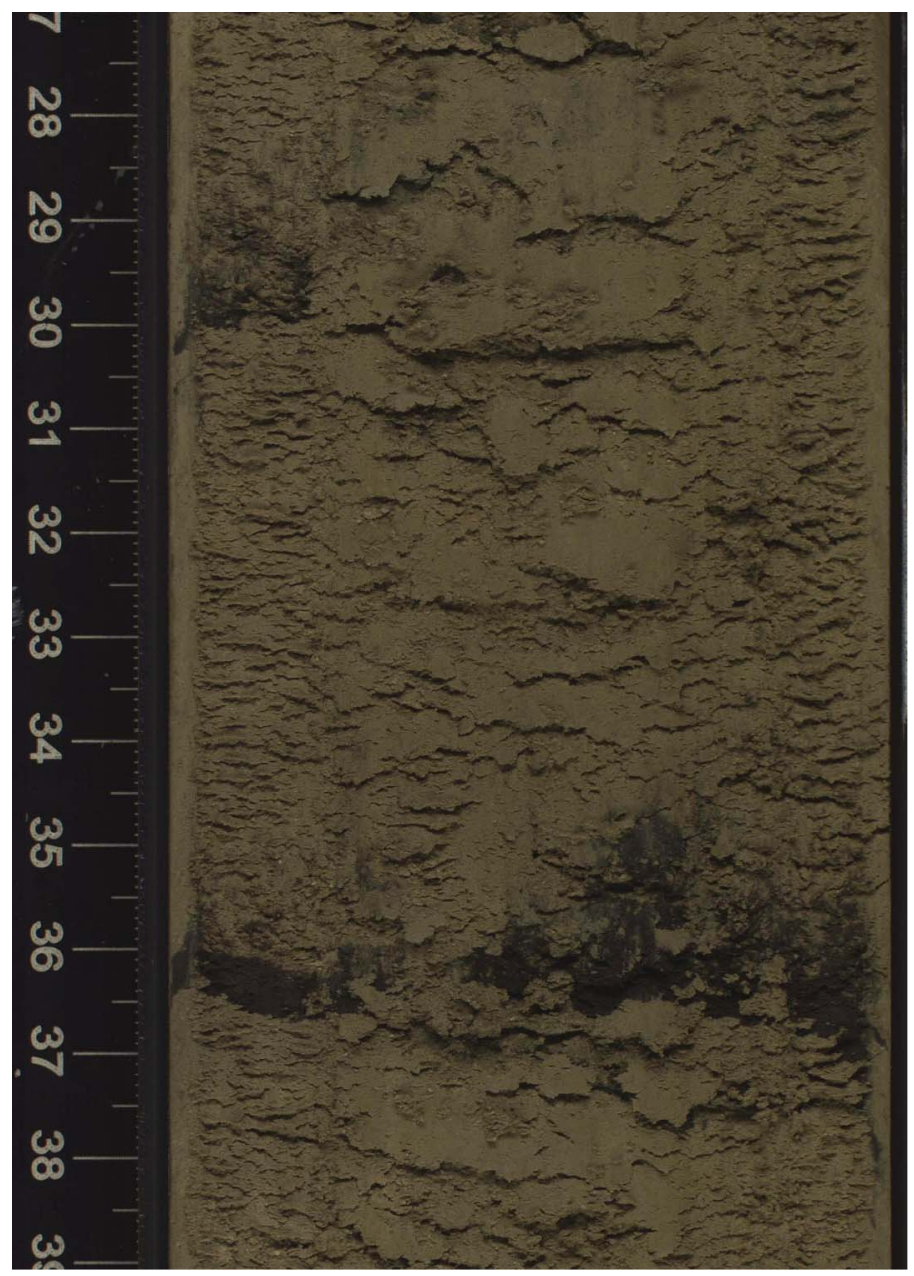


Figure F5. Representative core image of a chilled margin in Unit III (interval 334-U1381A-12R-2, 6-11 cm).

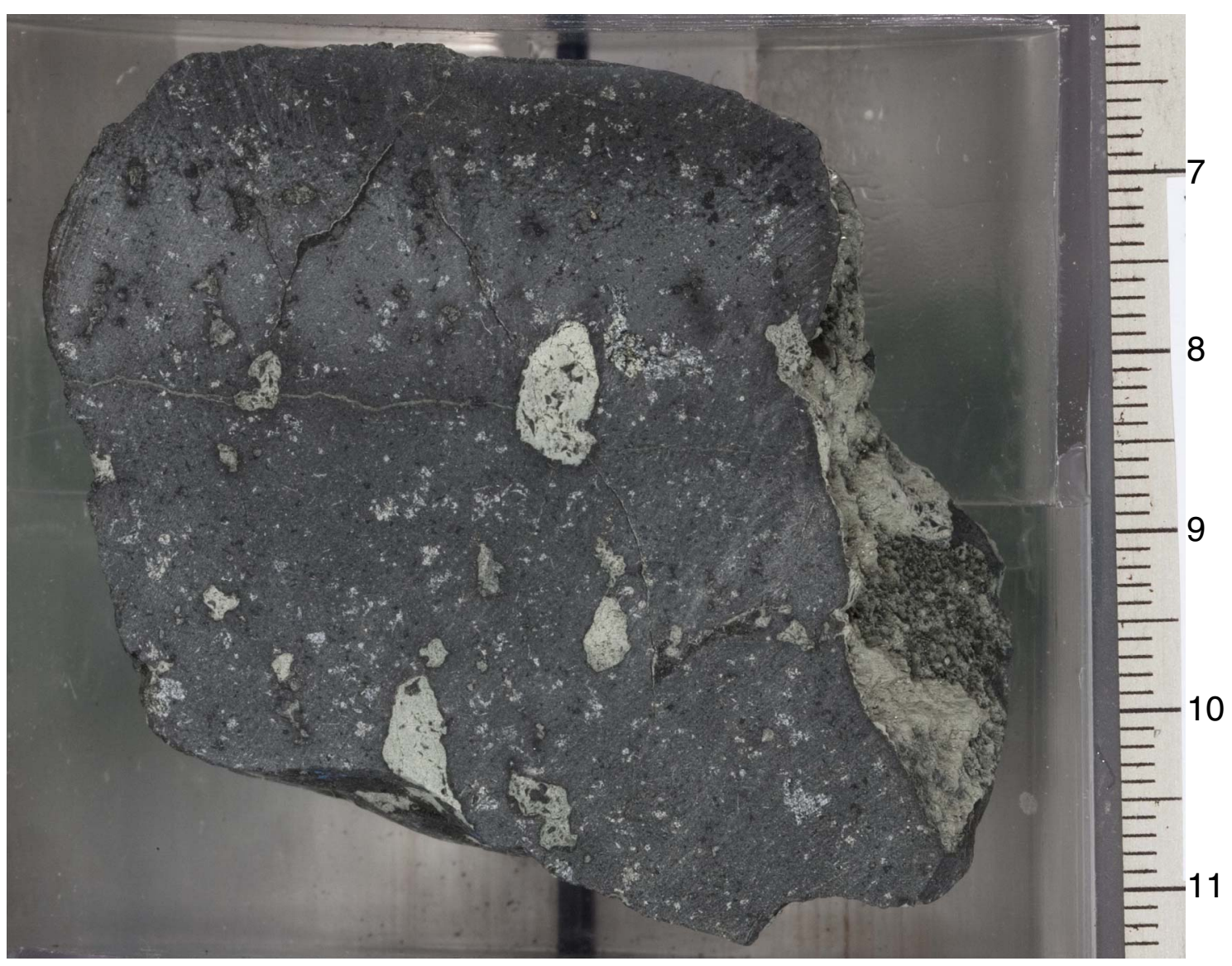


Figure F6. Core image of moderately plagioclase-phyric basalt with high vesicle content in Unit III (interval 334U1381A-14R-2, 130-136 cm).

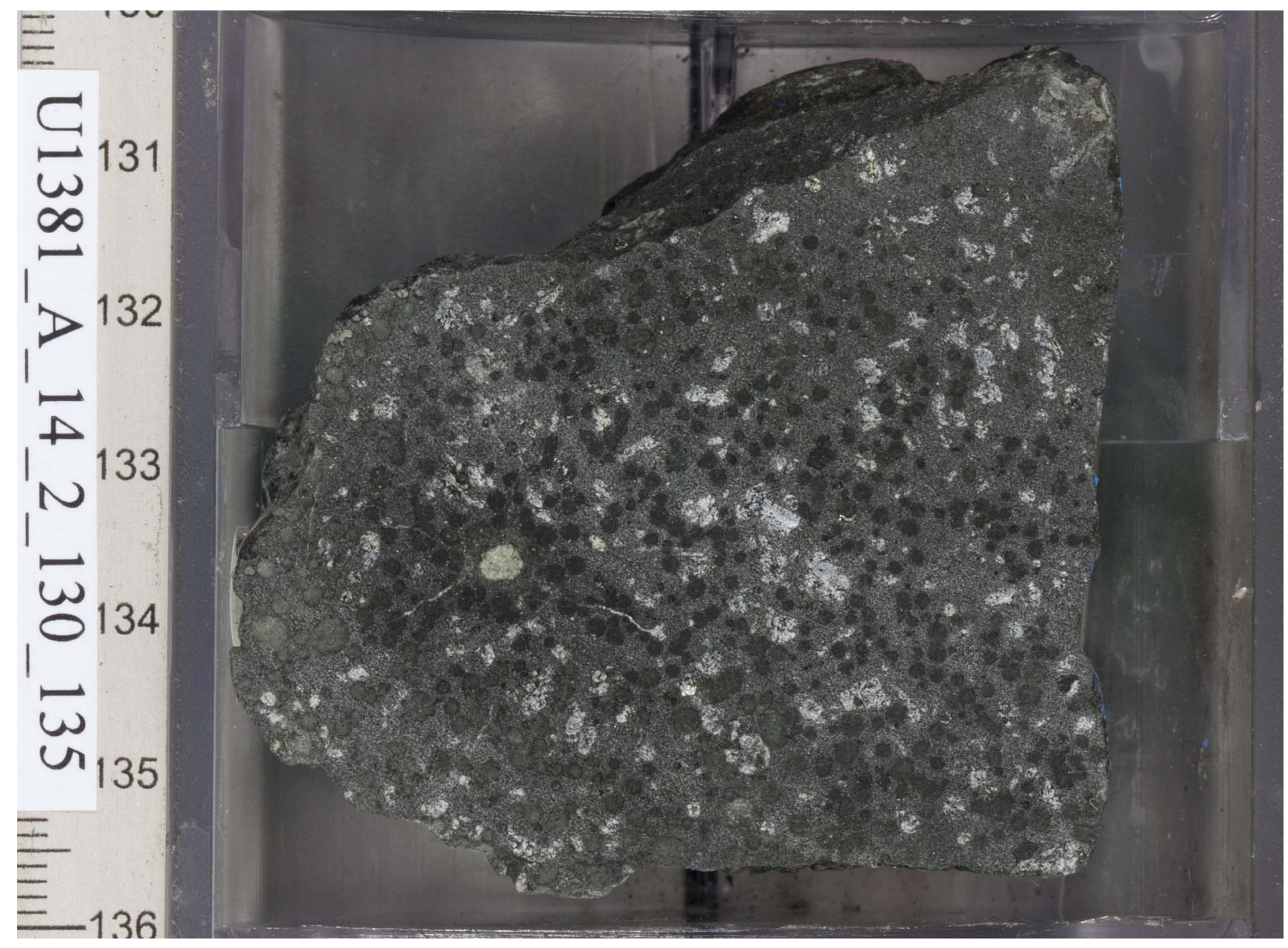


Figure F7. Representative core image of Unit III (interval 334-U1381A-18R-1, 26-33 cm).

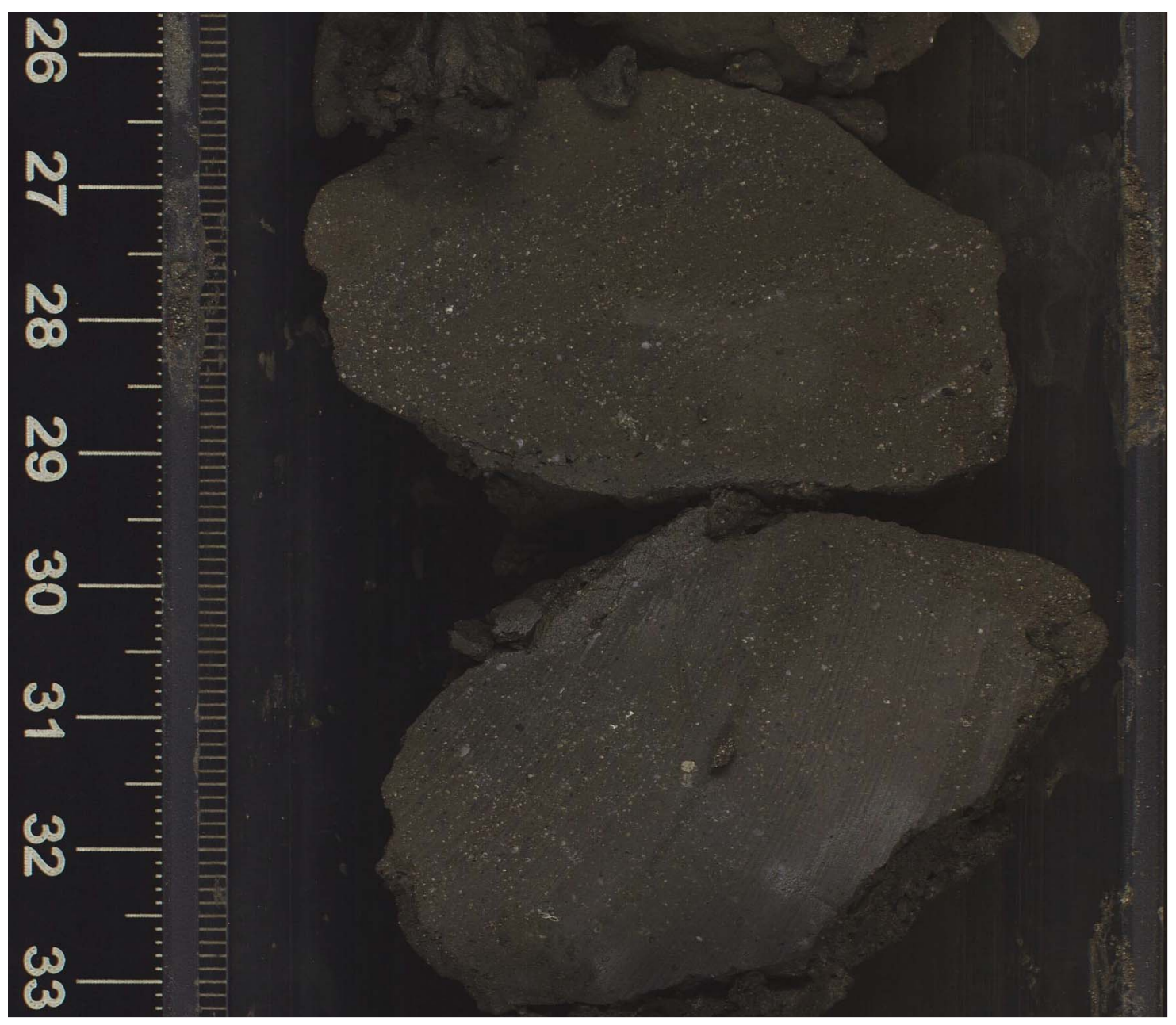


Figure F8. Representative core image of Unit III (interval 334-U1381A-24R-2, 72-80 cm).

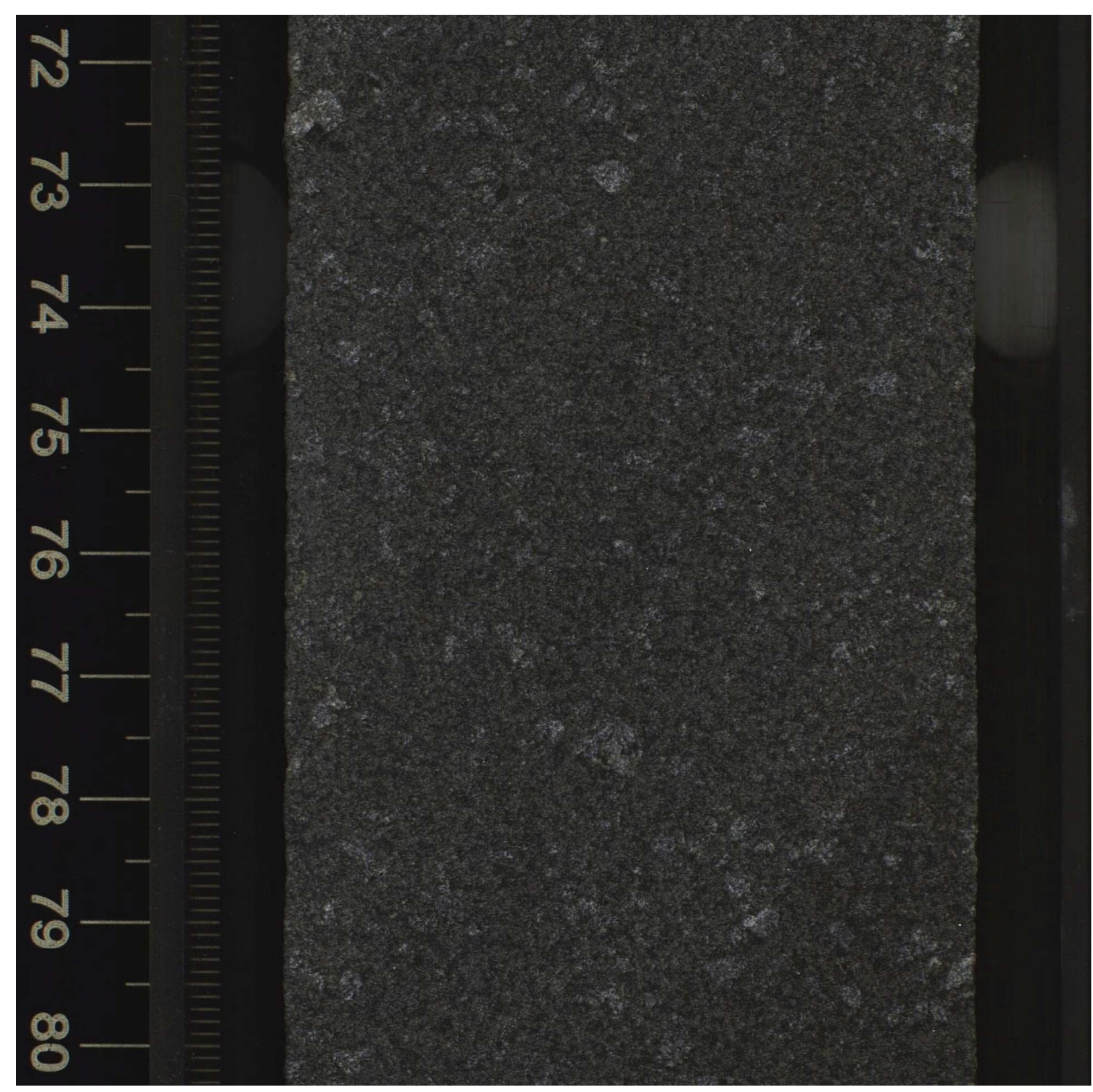


Figure F9. Representative core image of Unit III (interval 334-U1381A-26R-2, 2-9 cm).

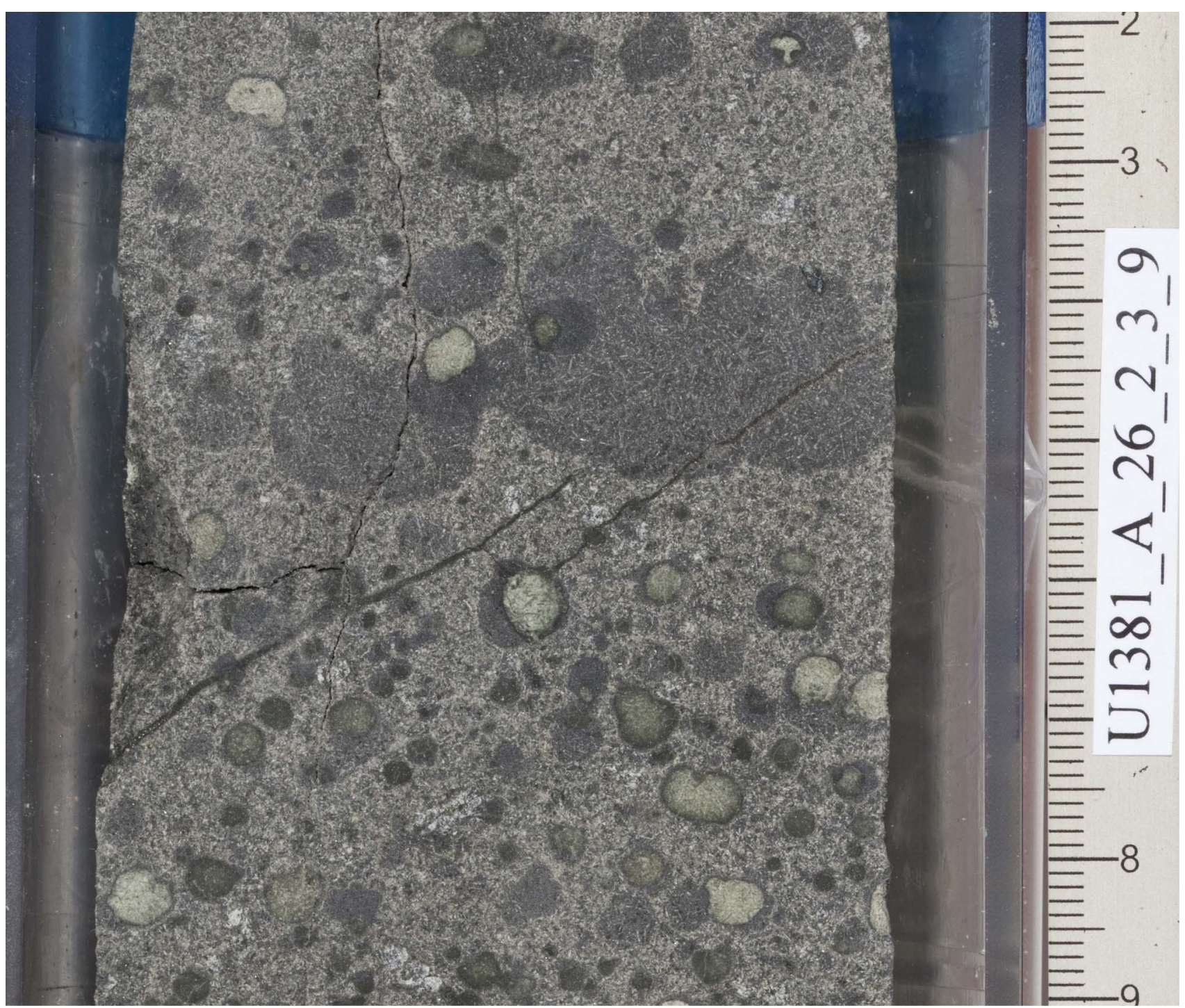


Figure F10. Core image of brownish dark gray, $34 \mathrm{~cm}$ thick silicified tephra layer with normal gradation from medium ash at the base to fine ash at the top. Tephra layer shows bioturbated in the upper part, transition into sediment above, a parallel laminated middle part, and a cross-bedded to massive coarser grained lower part (interval 334-U1381A-7R-1, $88 \mathrm{~cm}$, to 7R-2, $11 \mathrm{~cm}$ ).

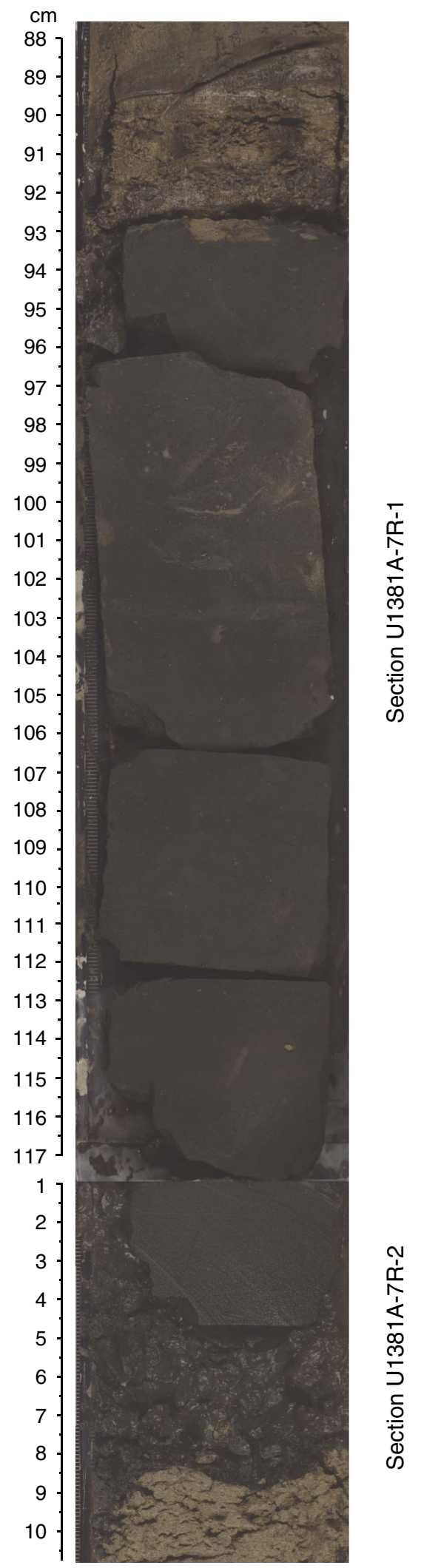


Figure F11. Plots of dips of bedding planes, fractures, faults, and mineral-filled veins as a function of depth, Hole U1381A.

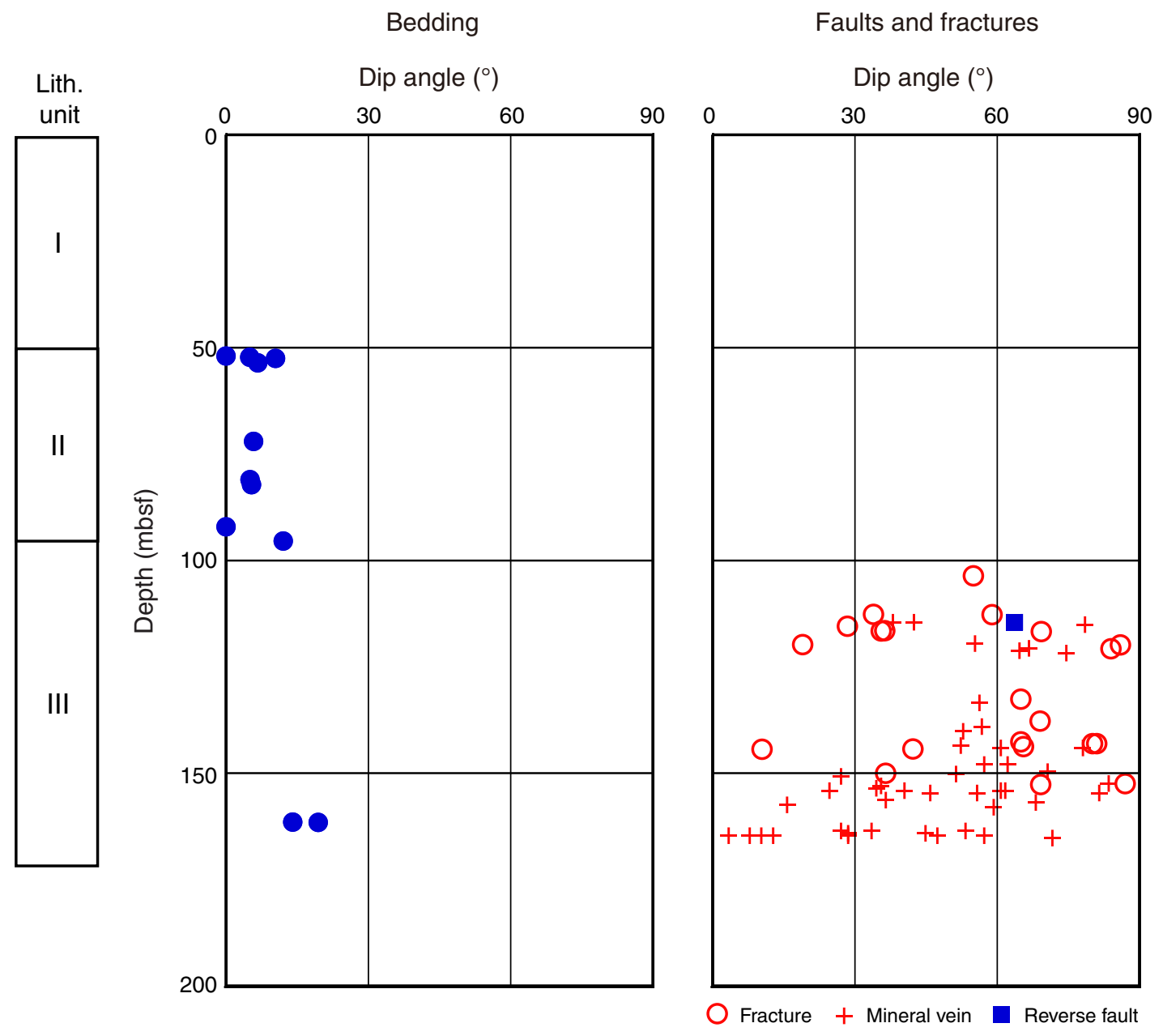


Figure F12. Core images of mineral-filled veins (calcite) and fractures, Hole U1381A. Fractures in the right panel are filled with alteration material (dark greenish clay).

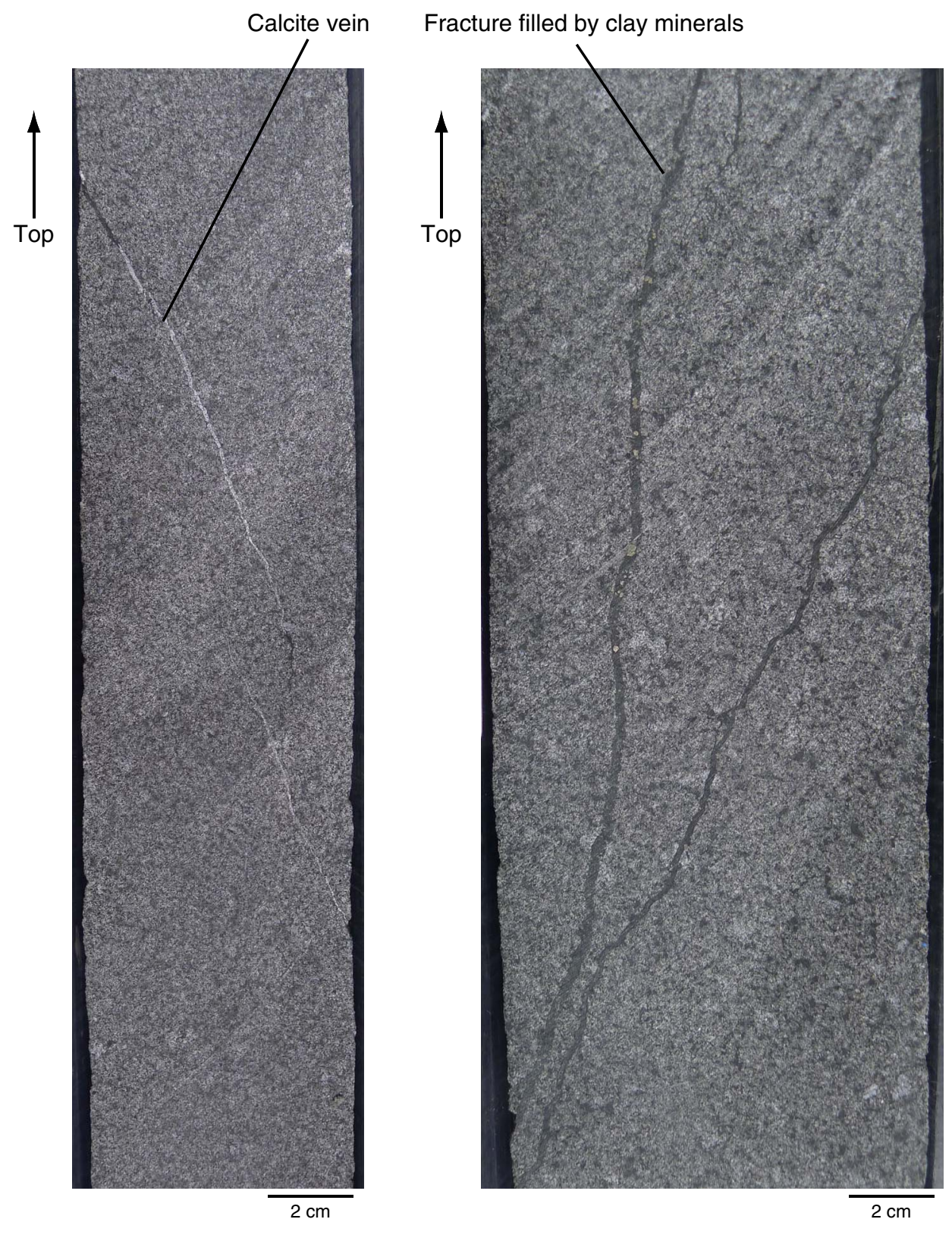

Interval 334-U1381A-21R-1, 52-77 cm

Interval 334-U1381A-21R-2, 8-33 cm 
Figure F13. Concentration-depth profiles, Site U1381.
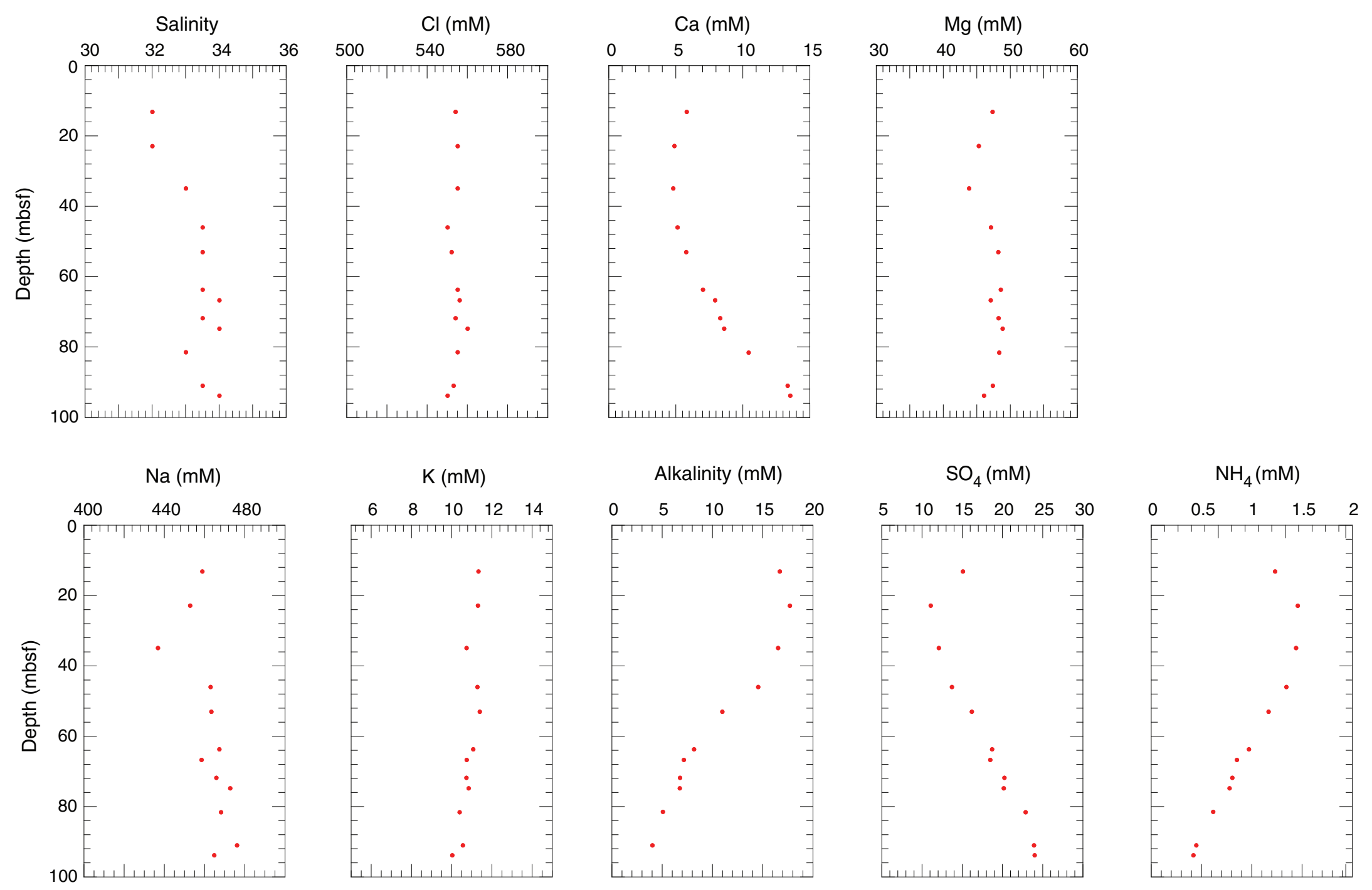
Figure F14. Plots of combined results of density and porosity measurements, Site U1381. A. Gamma ray attenuation density measured on the Whole-Round Multisensor Logger (black circles) and wet bulk density measured on discrete samples using the moisture and density (MAD) mass/volume method (red circles). B. Grain density measured on discrete samples using the MAD mass/volume method. C. Porosity determined using MAD Method C.

A Bulk density $\left(\mathrm{g} / \mathrm{cm}^{3}\right)$

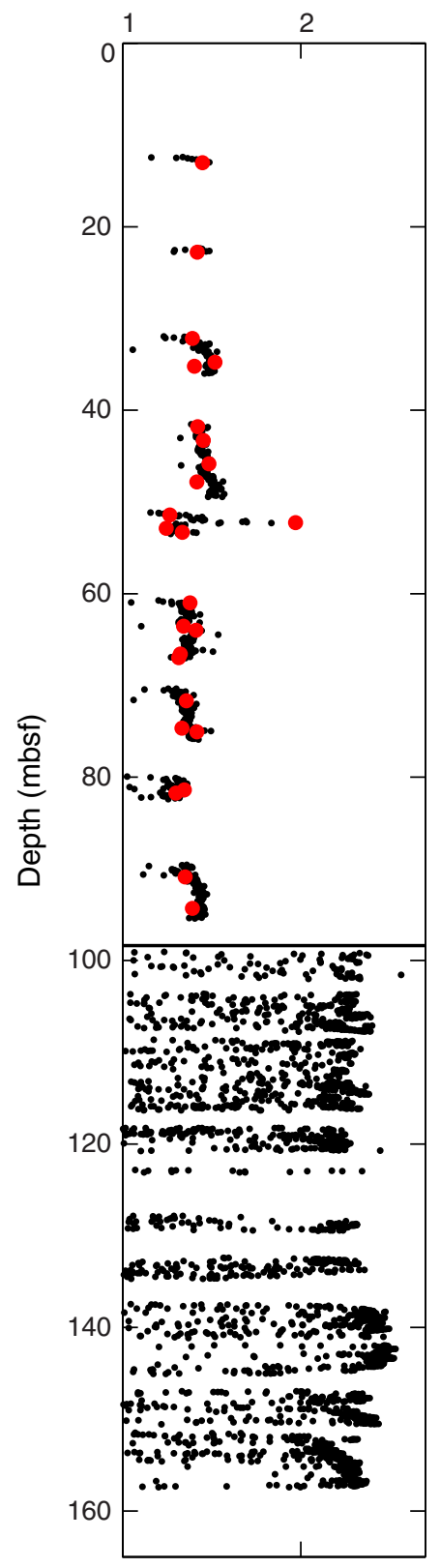

B Grain density $\left(\mathrm{g} / \mathrm{cm}^{3}\right)$

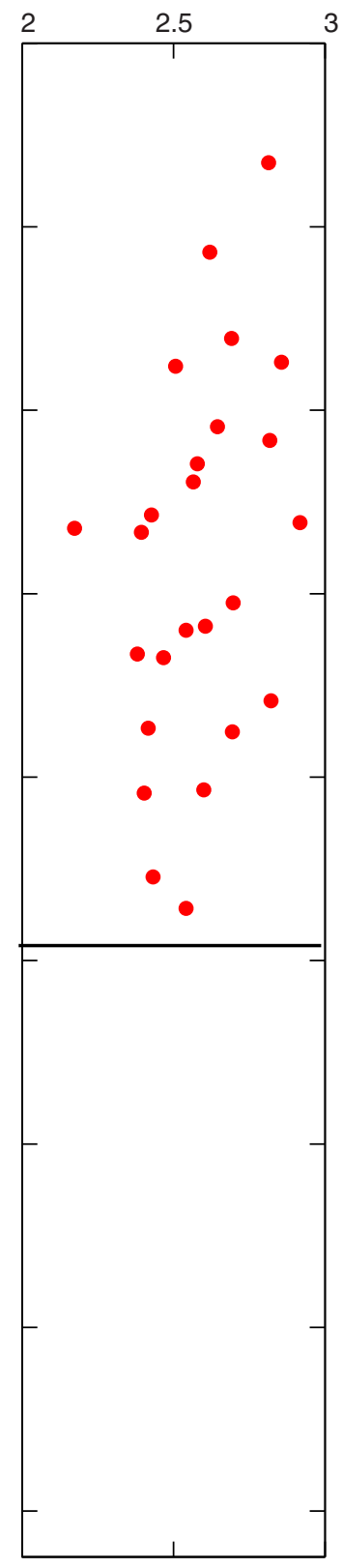

C Porosity (\%)

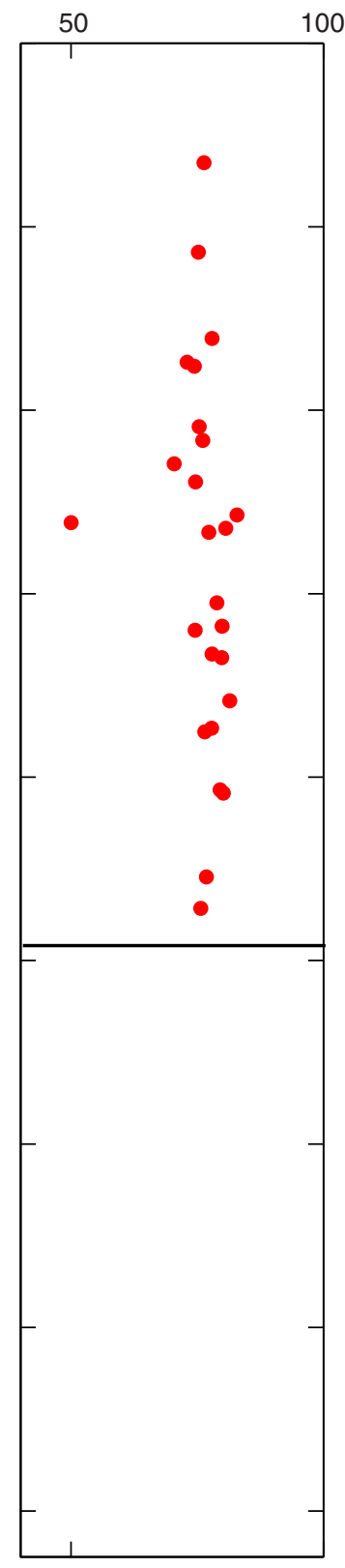


Figure F15. Plots of magnetic susceptibility as a function of depth, Site U1381. Volumetric magnetic susceptibility measurements were made on the Whole-Round Multisensor Logger and point measurements were made on the Section Half Multisensor Logger.
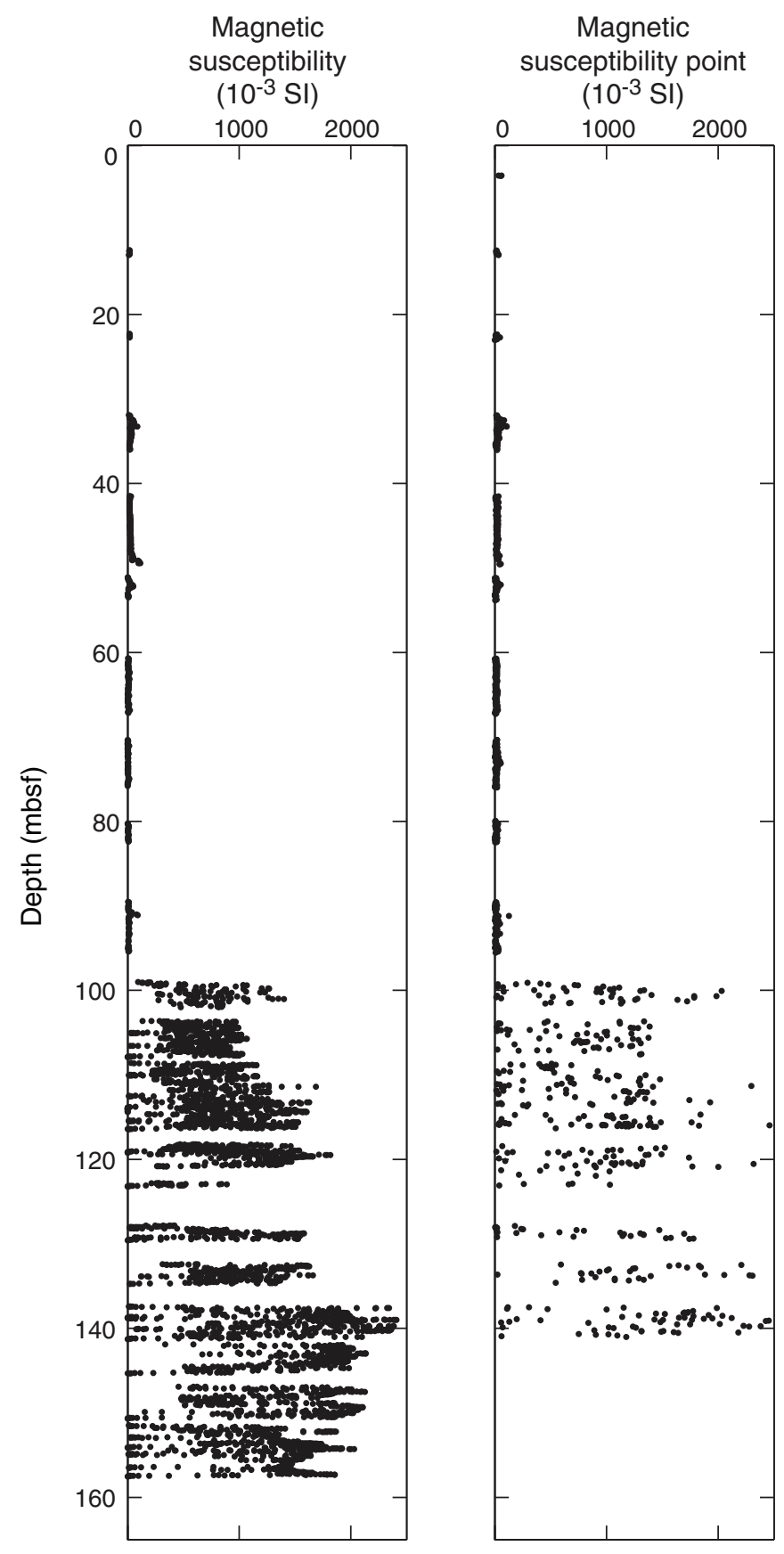
Figure F16. Plot of natural gamma radiation (NGR) as a function of depth, Site U1381.

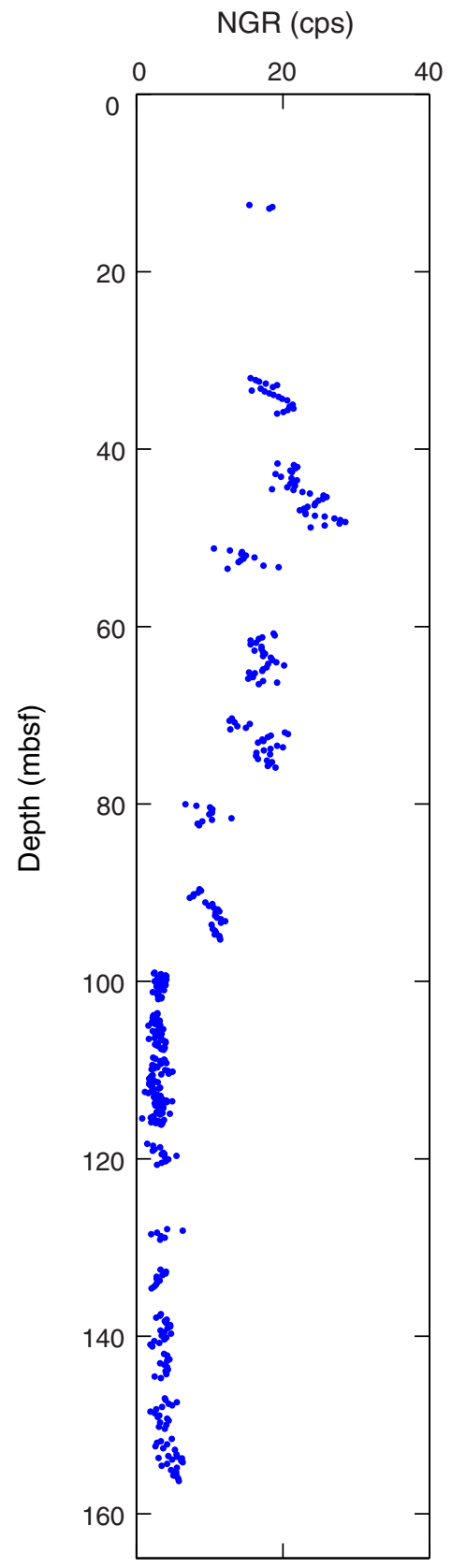


Figure F17. Plot of compressional wave velocity, Site U1381. $P$-wave velocity measured on discrete samples using the Section Half Multisensor Logger. WRMSL = Whole-Round Multisensor Logger.

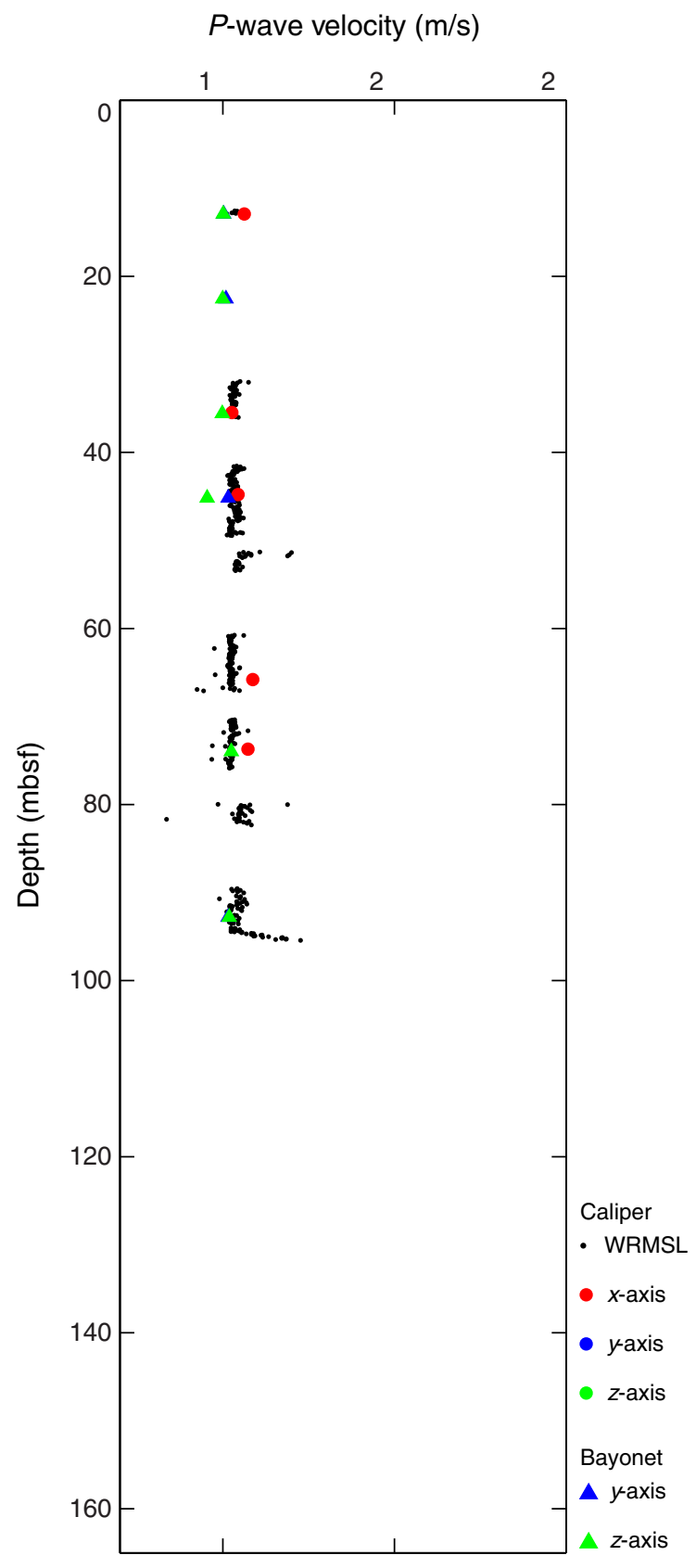


Figure F18. Plots of thermal data, Site U1381. A. Thermal conductivity values as a function of depth. Blue = needle-probe measurements in Hole U1381A, red = half-space measurements, green = needle-probe measurements in Hole U1381B. B. Equilibrium temperatures. Gradient (line) is best fit to data in least-squares sense.

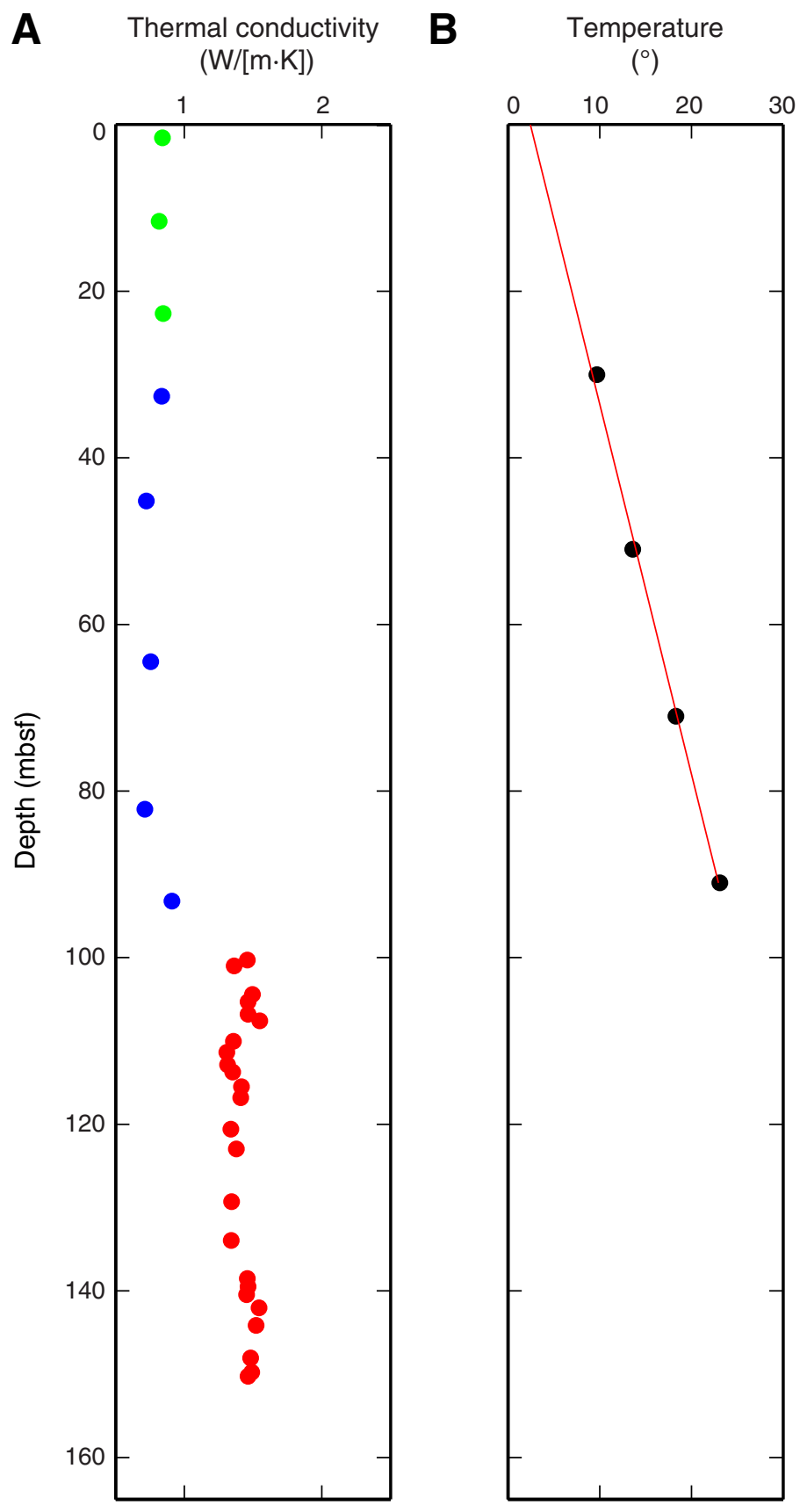


Figure F19. Plots of temperature-time series measured during the deployment of the Sediment Temperature Tool (SET) at Site U1381. Unshaded area shows data used for equilibrium temperature fit. Triangle shows beginning of fit and inverted triangle shows end of fit. (Continued on next page.)

Time after penetration (s)
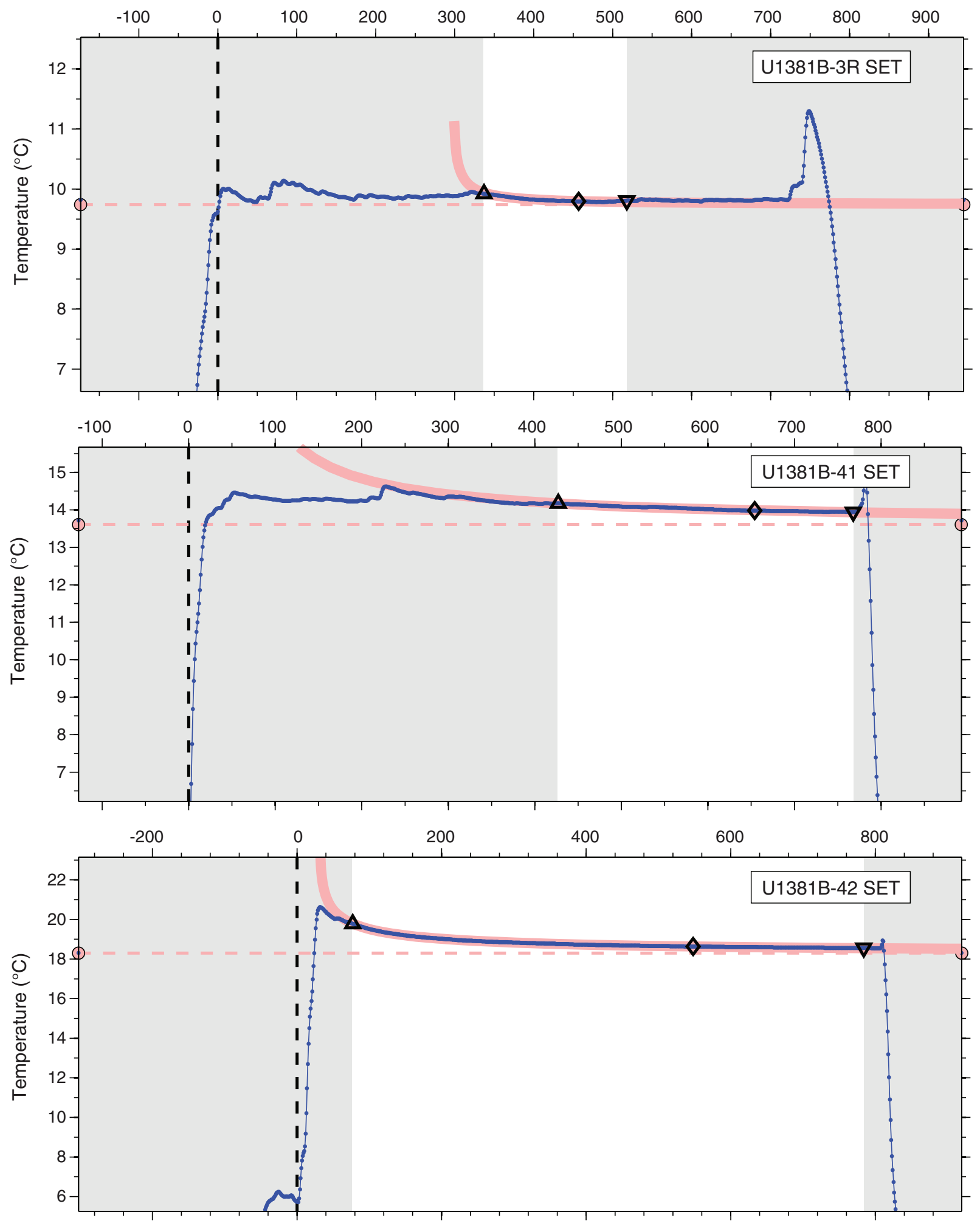
Figure F19 (continued).

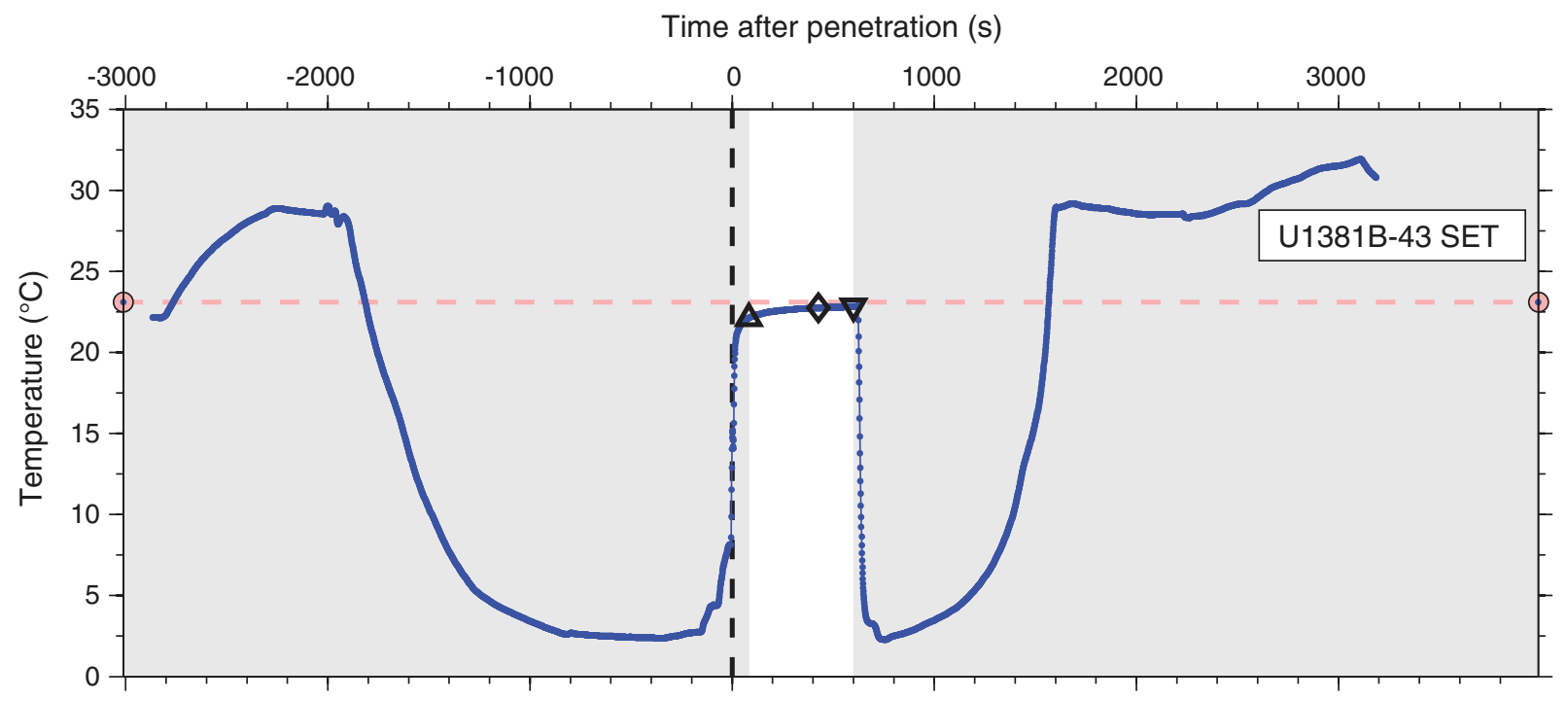


Figure F20. Plot of undrained shear strength measured using an automatic vane shear, Site U1381.

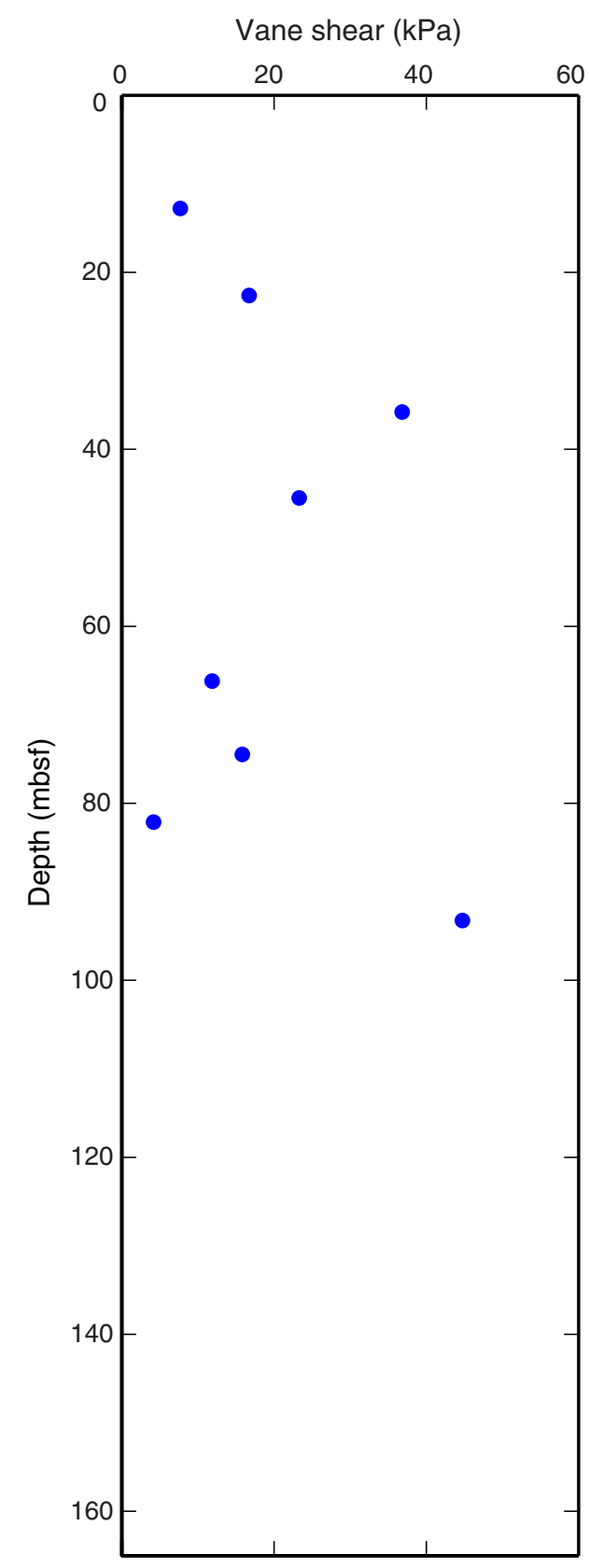


Figure F21. Plots of $\mathrm{L}^{*}, \mathrm{a}^{*}$, and $\mathrm{b}^{*}$ reflectance values vs. depth, Site U1381.

$L^{*}$

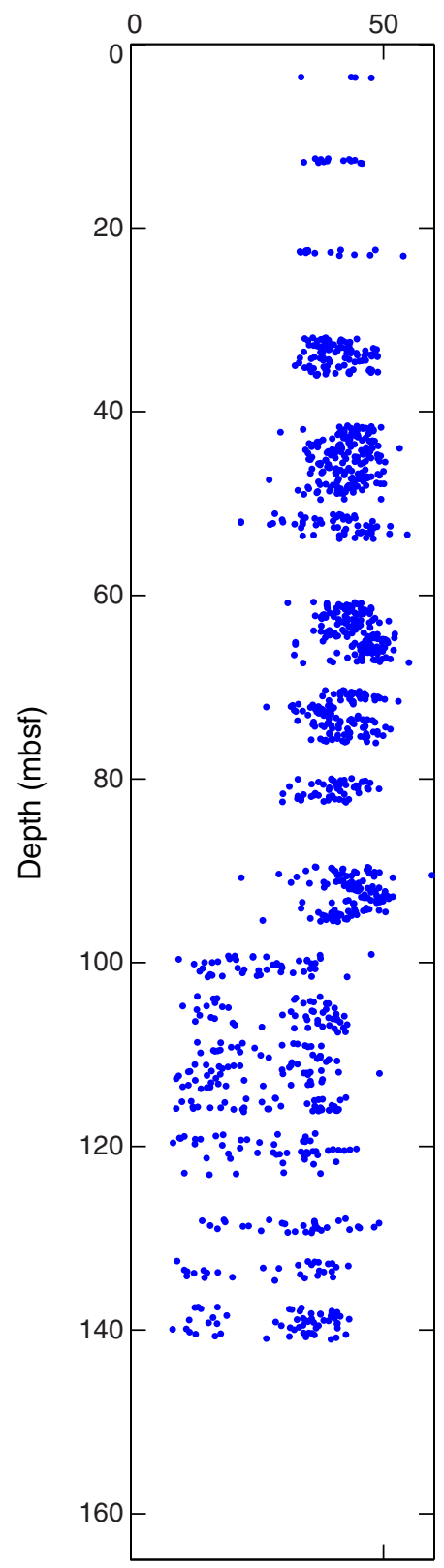

$a^{\star}$

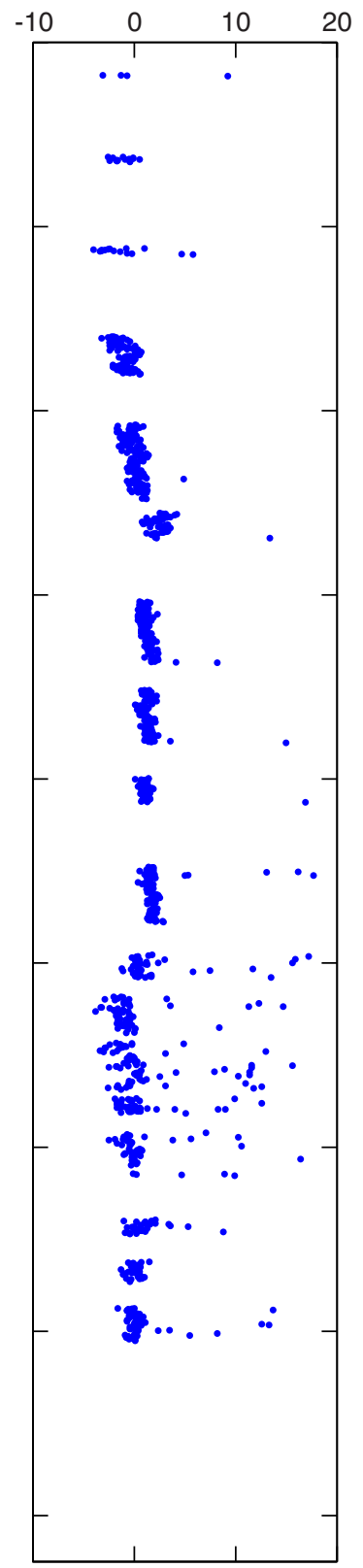

$b^{*}$

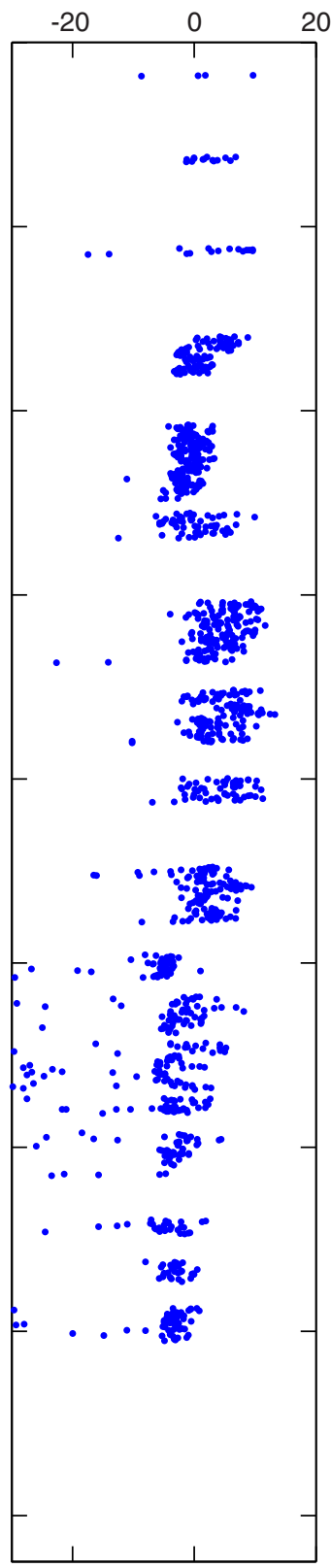


Figure F22. Plots of paleomagnetic measurements on sedimentary archive sections, Hole U1381A. Blue circles indicate discrete sample results of remanence vector endpoints. A. Natural remanent magnetization. B. Characteristic remanent magnetization after $15 \mathrm{mT}$ AF demagnetization. (Continued on next page.)

A
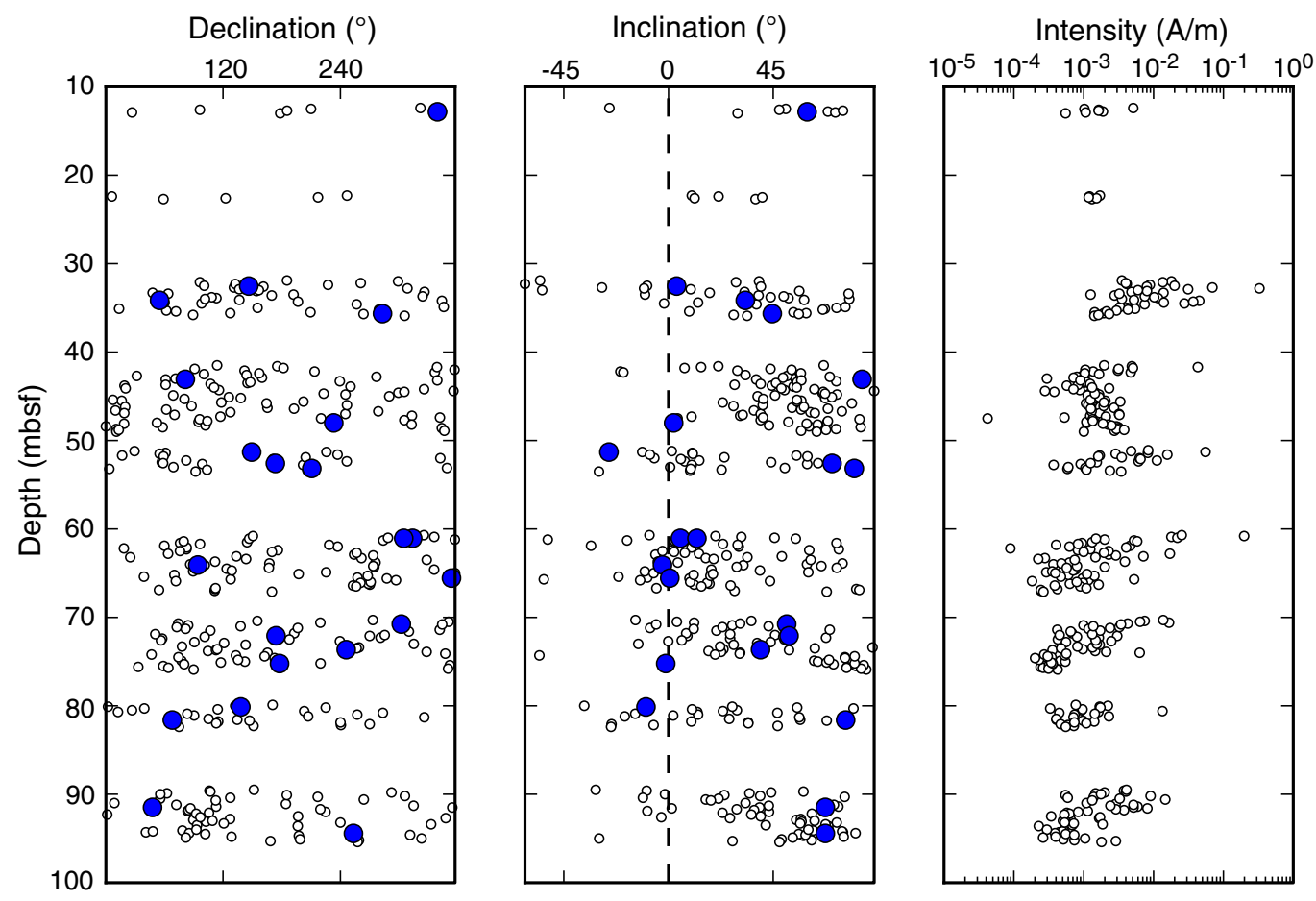

B
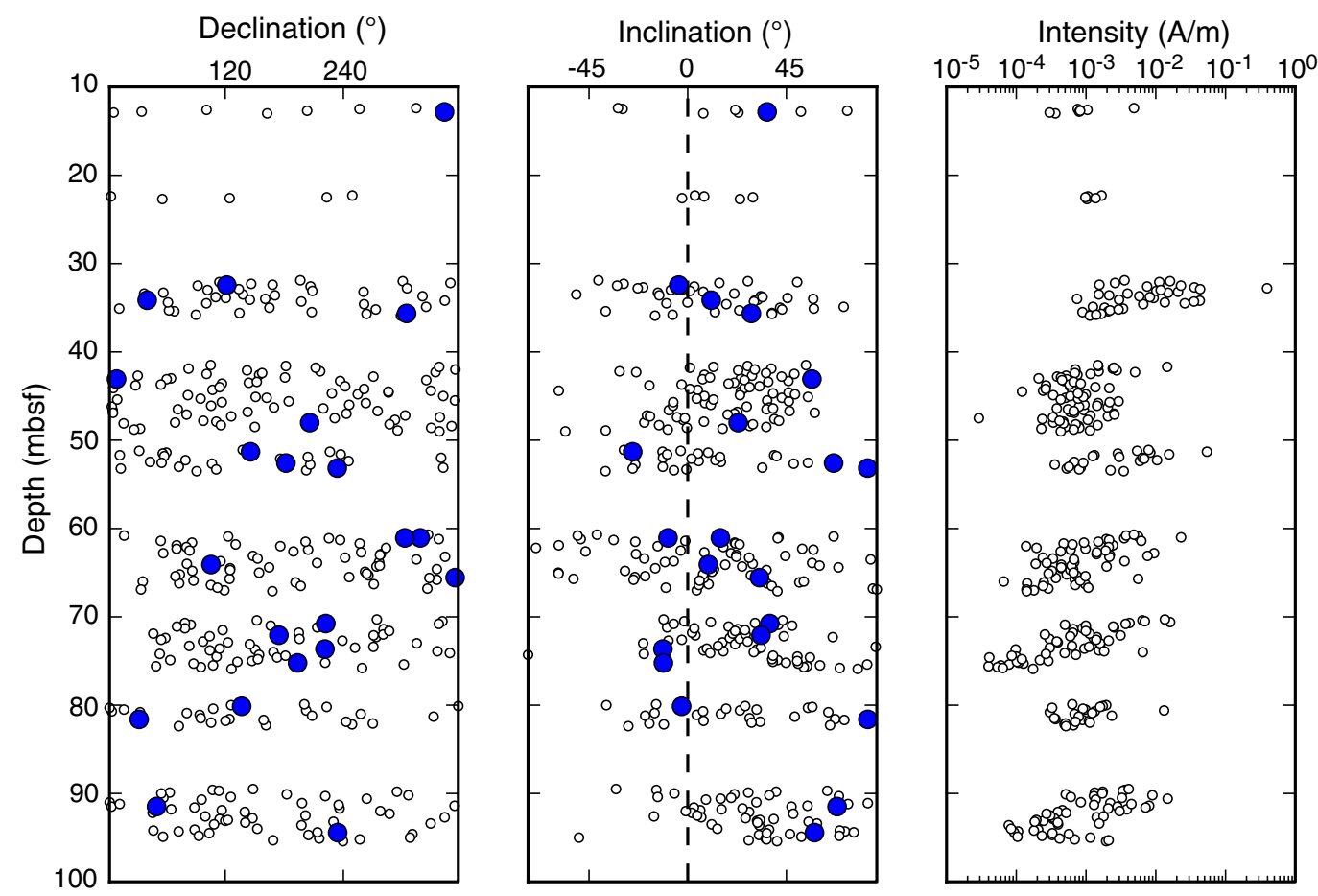
Figure F22 (continued). C. Characteristic remanent magnetization after $30 \mathrm{mT}$ AF demagnetization. D. Characteristic remanent magnetization after $40 \mathrm{mT}$ AF demagnetization.
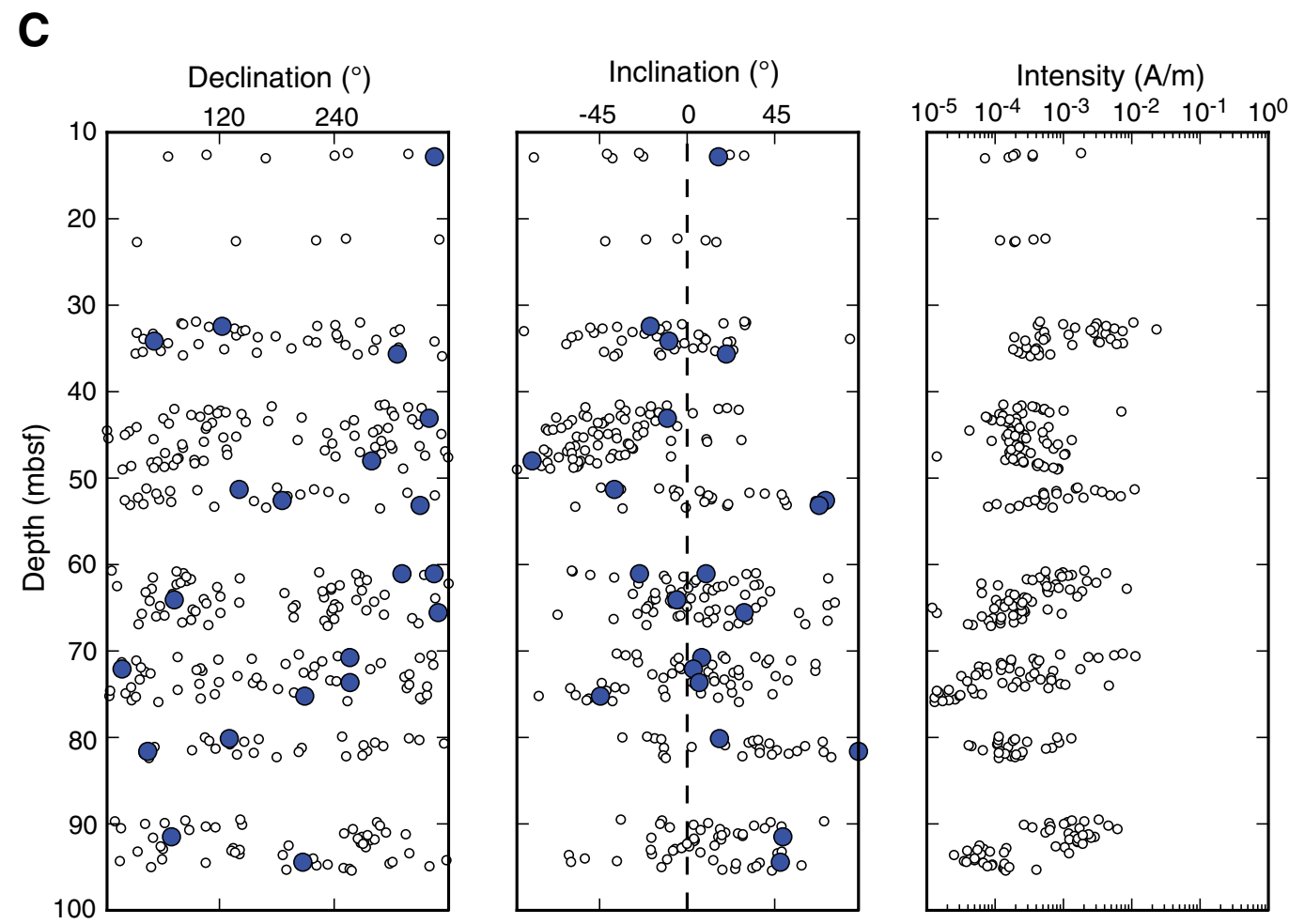

D

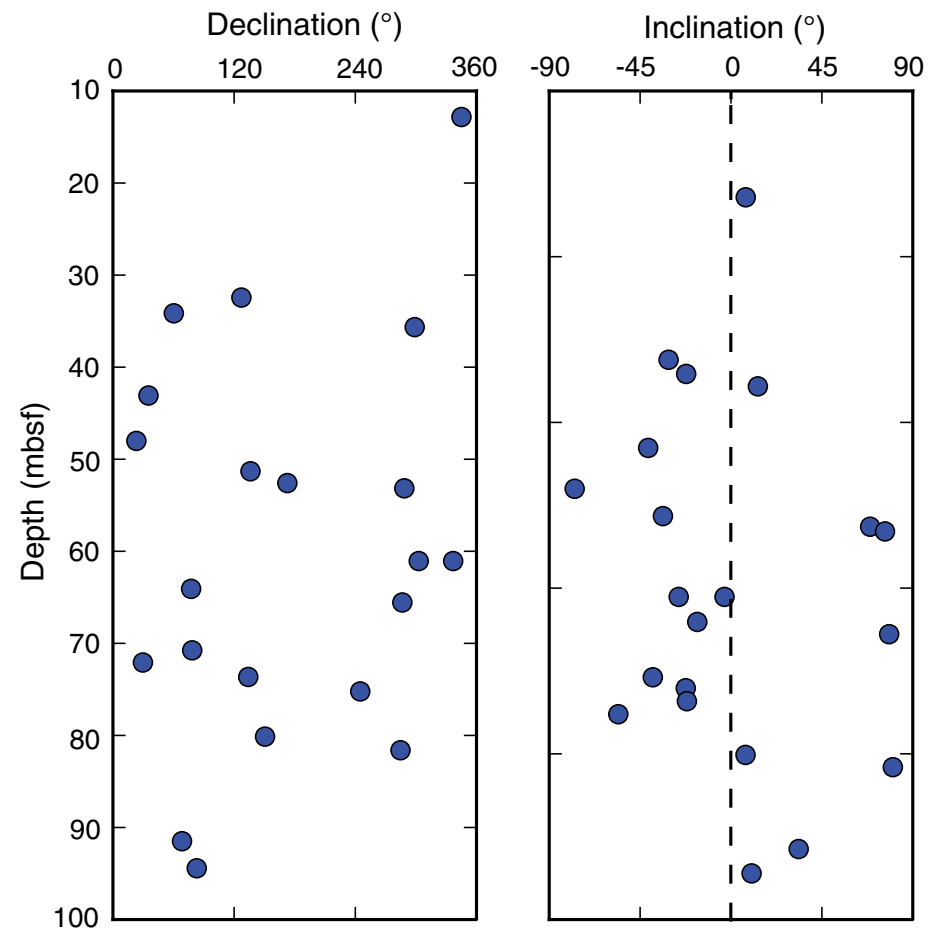


Figure F23. Plots of paleomagnetic measurements on basalt archive-half sections of (A) natural remanent magnetization (NRM) and (B) after $10 \mathrm{mT}$ AF demagnetization, Hole U1381A. Red stars indicate discrete sample results for NRM and characteristic remanent magnetization determined by principal component analysis.
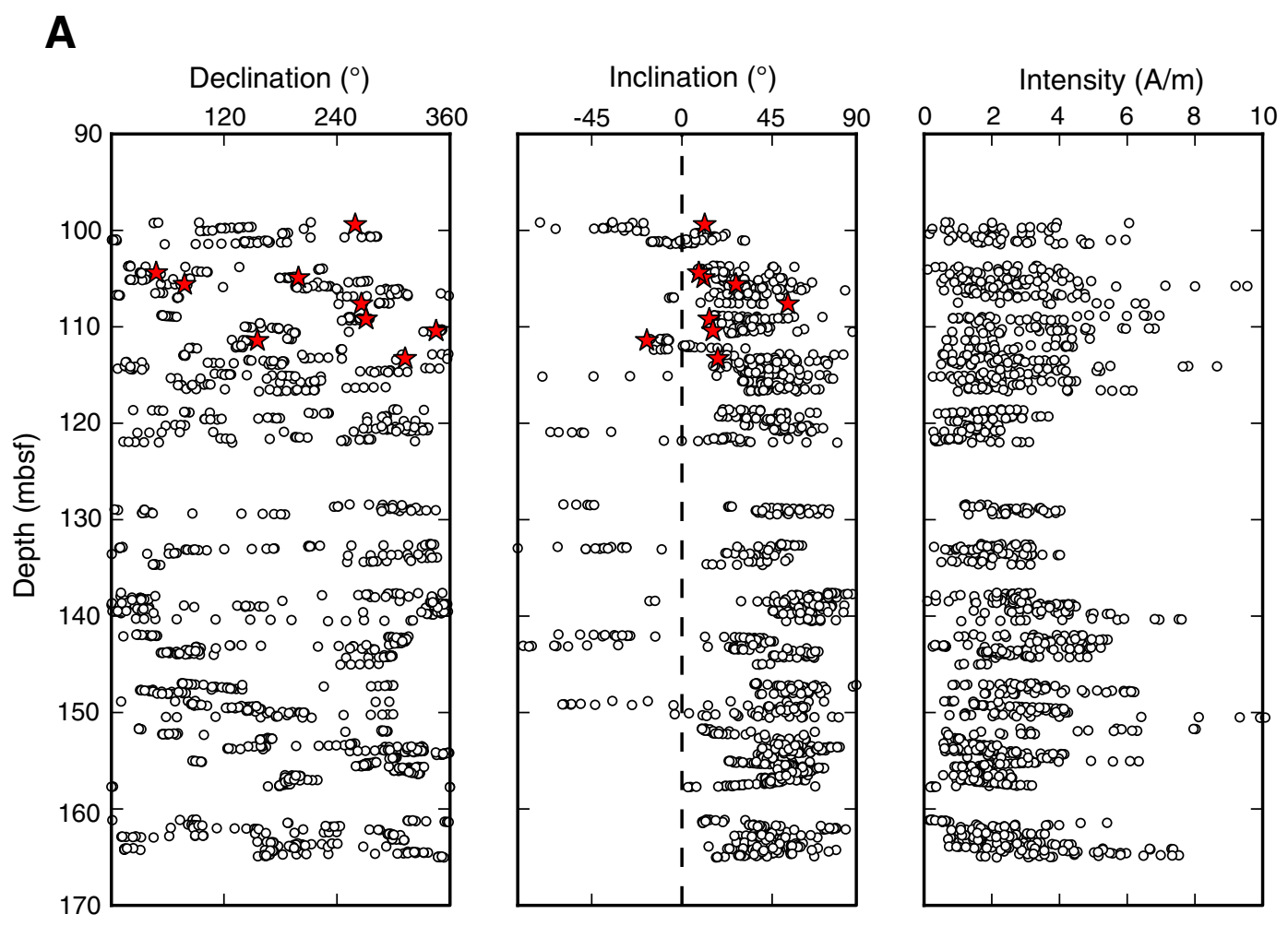

\section{B}
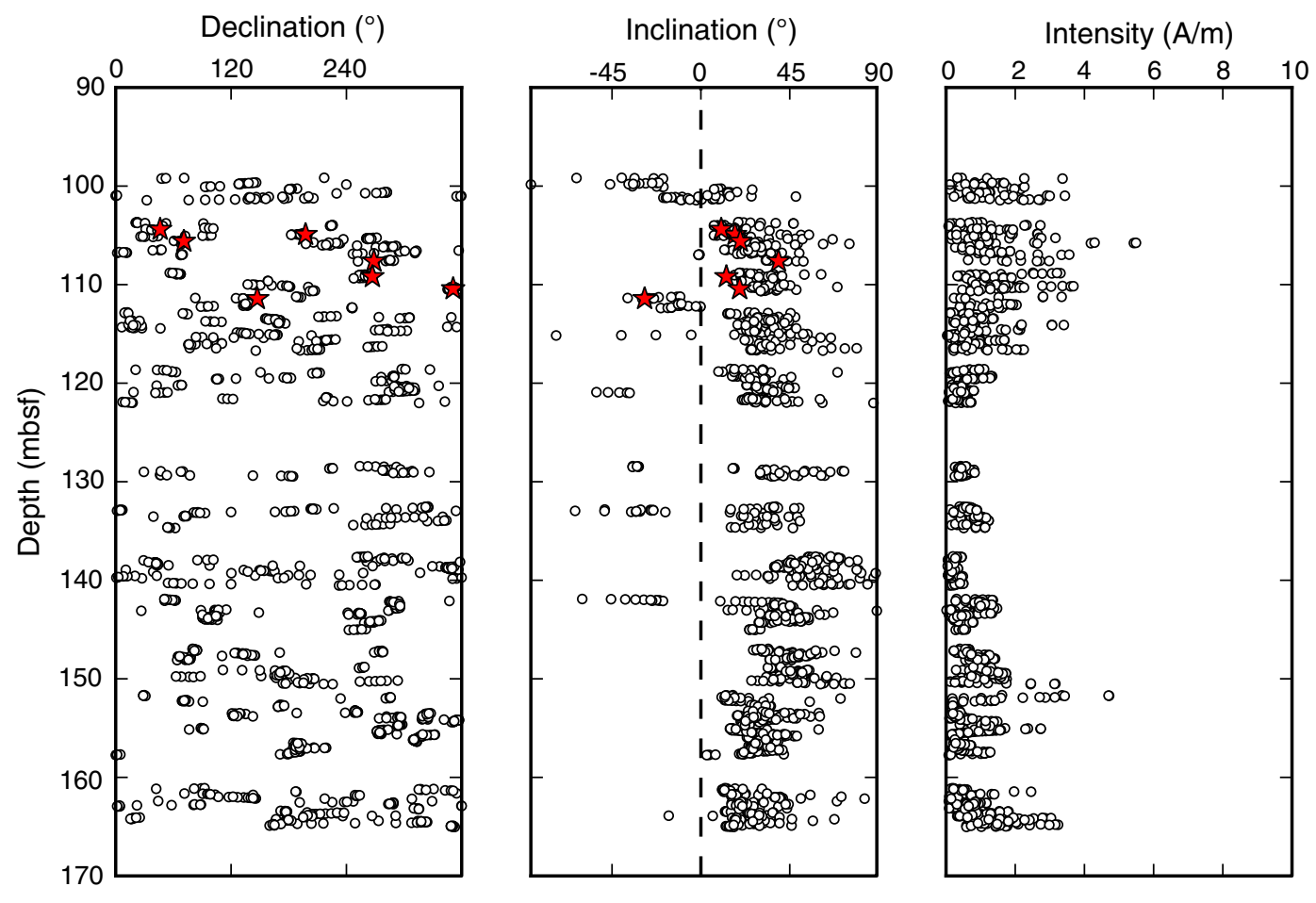
Figure F24. Representative vector endpoint diagrams (Zijderveld, 1967) of magnetization directions for sediment samples through stepwise AF demagnetization showing (A) multicomponent behavior with complicated path at higher AF field steps, (B) stable single ChRM component after removing the vertical overprint at $5 \mathrm{mT}$, and (C) unstable demagnetization behavior for a weakly magnetized sample. Open squares and solid circles represent the projection of the magnetization vector endpoints onto the vertical and horizontal planes, respectively. NRM = natural remanent magnetization.

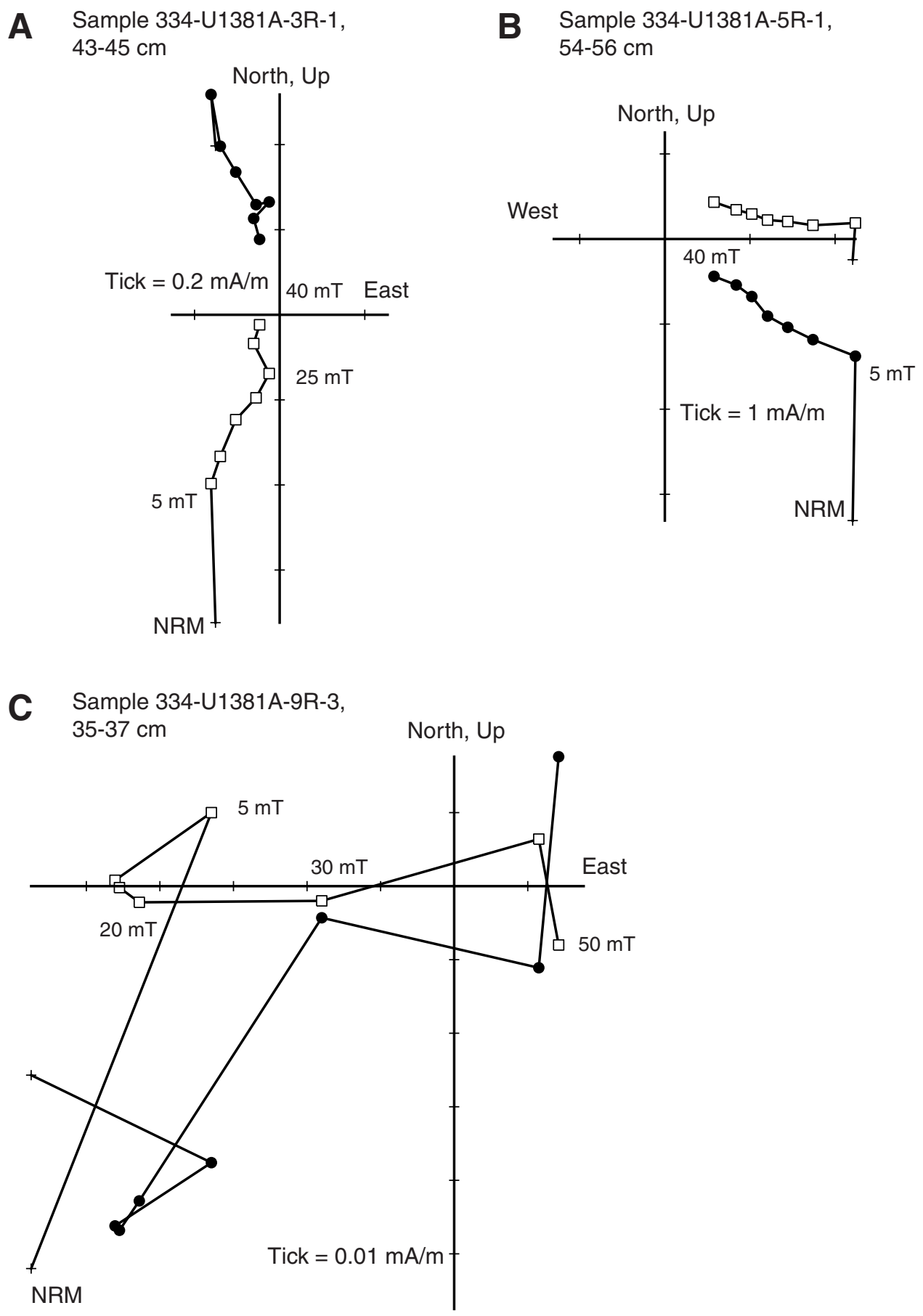


Figure F25. Representative vector endpoint diagrams (Zijderveld, 1967) of magnetization directions for discrete basaltic samples through (A, B) stepwise AF demagnetization and (C) stepwise thermal demagnetization. Both demagnetization techniques revealed well-defined remanence components. Sample in B shows negative inclination. Open squares and solid circles represent the projection of the magnetization vector endpoints onto the vertical and horizontal planes, respectively. $\mathrm{NRM}=$ natural remanent magnetization.

A Sample 334-U1381A-13R-1, $79-81 \mathrm{~cm}$

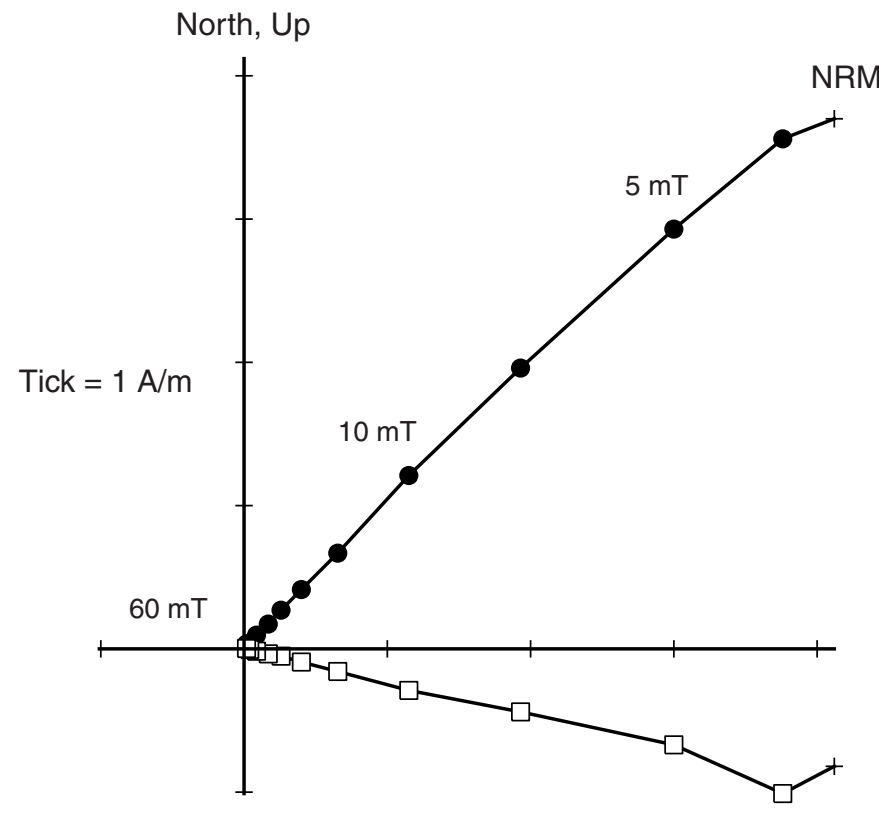

C Sample 334-U1381A-13R-3,

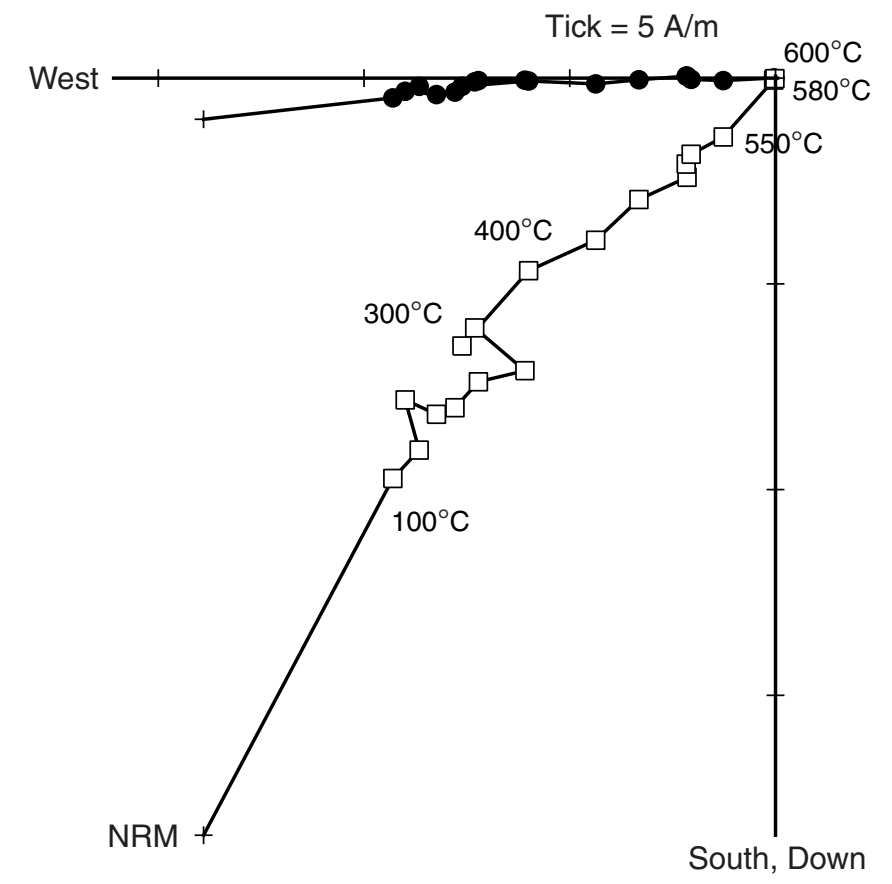

B Sample 334-U1381A-14R-2, $144-146 \mathrm{~cm}$

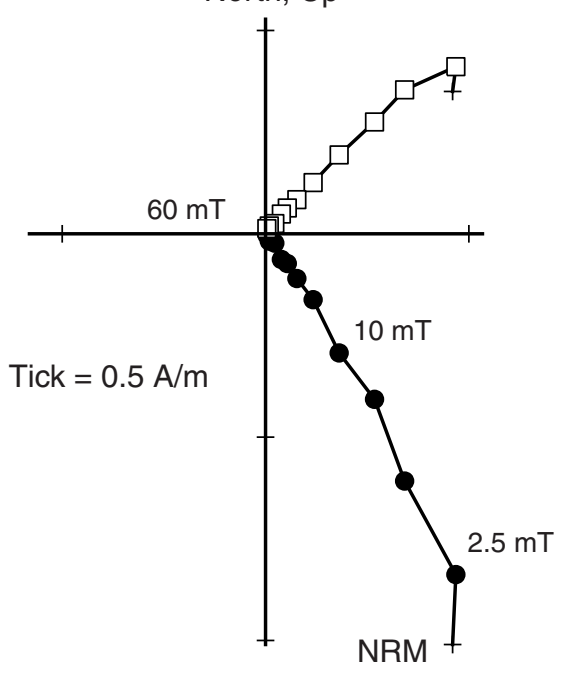


Figure F26. Plots of magnetization intensity change in basaltic samples during stepwise alternating-field (AF) demagnetization for selected discrete samples from basement cores, Hole U1381A.
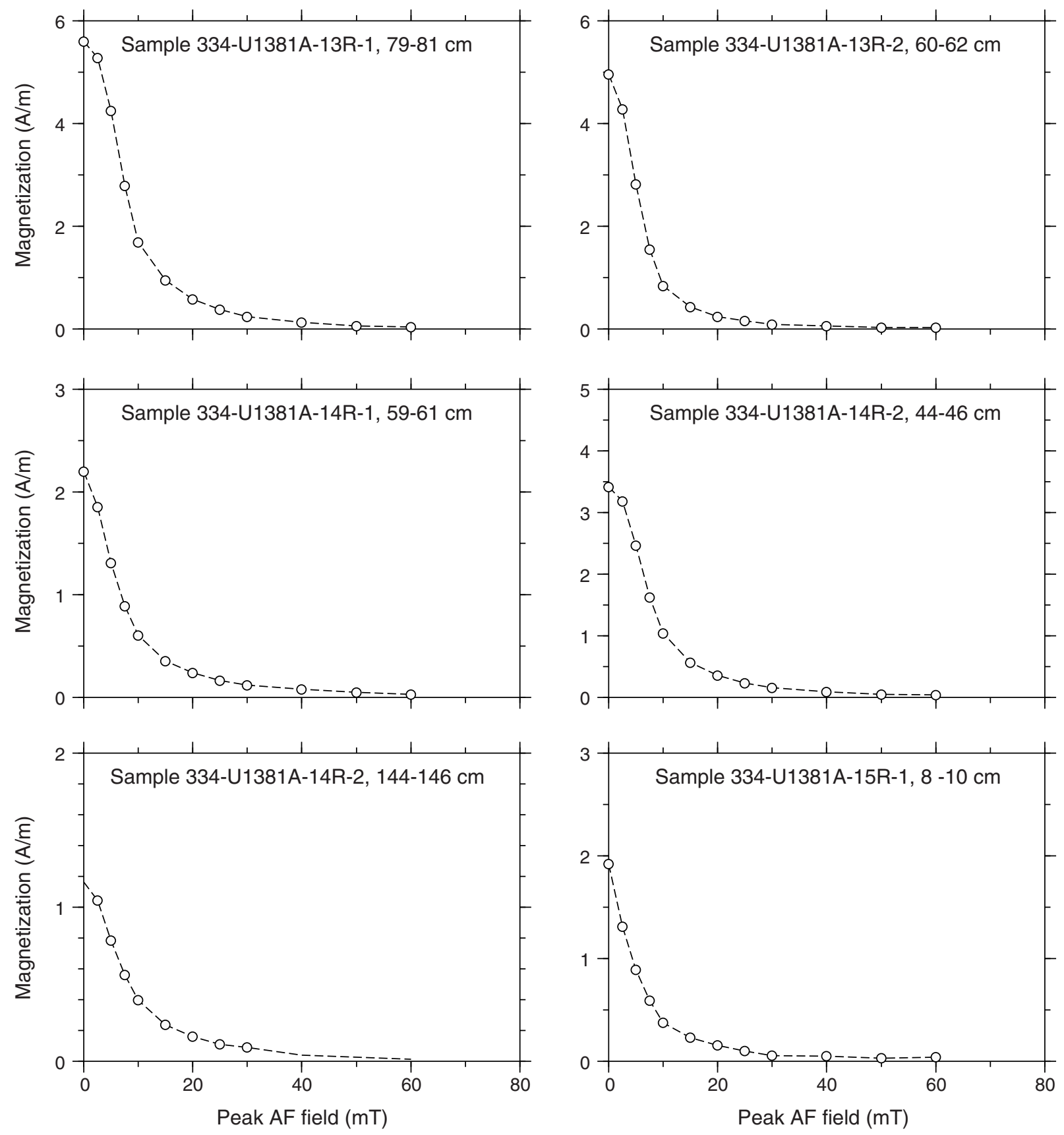
Figure F27. Plots of magnetization intensity change in basaltic samples during stepwise thermal demagnetization, Hole U1381A.
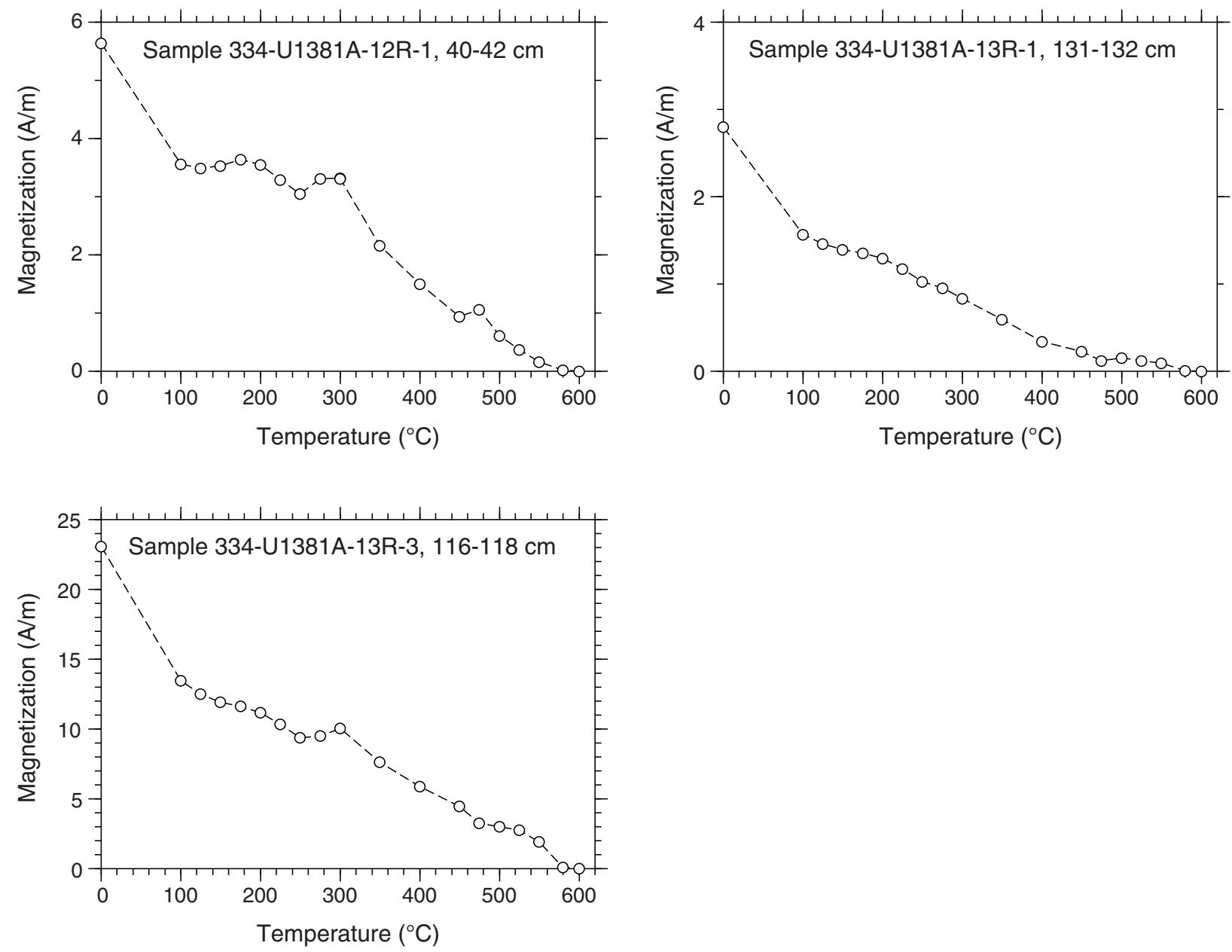
Table T1. Operations summary, Site U1381. (Continued on next page.)

\section{Hole U1381A}

Latitude: $8^{\circ} 25.7150^{\prime} \mathrm{N}$

Longitude: $84^{\circ} 9.4690^{\prime} \mathrm{W}$

Time on hole (h): 76.8 (2130 h, 8 April-0215 h, 12 April 2011)

Seafloor (drill pipe measurement below rig floor, m DRF): 2080.2

Distance between rig floor and sea level $(\mathrm{m}): 11.1$

Water depth (drill pipe measurement from sea level, mbsl): 2069.1

Total penetration (drilling depth below seafloor, m DSF): 164.1

Total length of cored interval $(\mathrm{m}): 164.1$

Total core recovered $(\mathrm{m}): 73.86$

Recovery (\%): 45

Drilled interval $(\mathrm{m}): 0$

Total number of cores: 26

Hole U1381B

Latitude: $8^{\circ} 25.7149^{\prime} \mathrm{N}$

Longitude: $84^{\circ} 9.4805^{\prime} \mathrm{W}$

Time on hole (h): 16.8 (0215-1900 h, 12 April 2011)

Seafloor (drill pipe measurement below rig floor, m DRF): 2080.2

Distance between rig floor and sea level $(\mathrm{m}): 11.1$

Water depth (drill pipe measurement from sea level, mbsl): 2069.1

Total penetration (drilling depth below seafloor, $\mathrm{m} \mathrm{DSF}$ ): 9.0

Total length of cored interval $(\mathrm{m}): 2.0$

Total core recovered $(\mathrm{m}): 15.98$

Recovery (\%): 55

Drilled interval (m): 61.0

Total number of cores: 3

\begin{tabular}{|c|c|c|c|c|c|c|c|c|c|}
\hline \multirow[b]{2}{*}{ Core } & \multirow[b]{2}{*}{$\begin{array}{c}\text { Date } \\
(2011)\end{array}$} & \multirow[b]{2}{*}{$\begin{array}{l}\text { Time } \\
\text { (h) }\end{array}$} & \multicolumn{2}{|c|}{ Depth DSF (m) } & \multirow{2}{*}{$\begin{array}{l}\text { Interval } \\
\text { advanced } \\
\text { (m) }\end{array}$} & \multicolumn{2}{|c|}{ Depth CSF (m) } & \multirow{2}{*}{$\begin{array}{l}\text { Length of core } \\
\text { recovered } \\
(\mathrm{m})\end{array}$} & \multirow[b]{2}{*}{$\begin{array}{c}\text { Recovery } \\
\text { (\%) }\end{array}$} \\
\hline & & & $\begin{array}{l}\text { Top of cored } \\
\text { interval }\end{array}$ & $\begin{array}{l}\text { Bottom of } \\
\text { cored interval }\end{array}$ & & $\begin{array}{l}\text { Top of cored } \\
\text { interval }\end{array}$ & $\begin{array}{l}\text { Bottom of } \\
\text { cored interval }\end{array}$ & & \\
\hline \multicolumn{10}{|c|}{ 334-U1381A- } \\
\hline $1 \mathrm{R}$ & $09 \mathrm{Apr}$ & 1045 & 0.0 & 3.5 & 3.5 & 0.0 & 0.0 & 0.00 & 0 \\
\hline $2 \mathrm{R}$ & $09 \mathrm{Apr}$ & 1140 & 3.5 & 12.4 & 8.9 & 3.5 & 3.7 & 0.19 & 2 \\
\hline $3 R$ & $09 \mathrm{Apr}$ & 1225 & 12.4 & 22.3 & 9.9 & 12.4 & 13.4 & 0.99 & 10 \\
\hline $4 \mathrm{R}$ & $09 \mathrm{Apr}$ & 1310 & 22.3 & 31.9 & 9.6 & 22.3 & 23.0 & 0.73 & 8 \\
\hline $5 \mathrm{R}$ & $09 \mathrm{Apr}$ & 1350 & 31.9 & 41.5 & 9.6 & 31.9 & 36.1 & 4.19 & 44 \\
\hline $6 \mathrm{R}$ & $09 \mathrm{Apr}$ & 1440 & 41.5 & 51.1 & 9.6 & 41.5 & 49.6 & 8.14 & 85 \\
\hline $7 R$ & $09 \mathrm{Apr}$ & 1540 & 51.1 & 60.7 & 9.6 & 51.1 & 53.9 & 2.76 & 29 \\
\hline $8 \mathrm{R}$ & $09 \mathrm{Apr}$ & 1620 & 60.7 & 70.3 & 9.6 & 60.7 & 67.4 & 6.66 & 69 \\
\hline $9 \mathrm{R}$ & $09 \mathrm{Apr}$ & 1710 & 70.3 & 79.9 & 9.6 & 70.3 & 76.1 & 5.81 & 61 \\
\hline $10 \mathrm{R}$ & $09 \mathrm{Apr}$ & 1750 & 79.9 & 89.5 & 9.6 & 79.9 & 82.5 & 2.63 & 27 \\
\hline $11 \mathrm{R}$ & $09 \mathrm{Apr}$ & 1915 & 89.5 & 99.0 & 9.5 & 89.5 & 95.6 & 6.07 & 64 \\
\hline $12 \mathrm{R}$ & $09 \mathrm{Apr}$ & 2225 & 99.0 & 103.6 & 4.6 & 99.0 & 102.0 & 2.32 & 50 \\
\hline $13 R$ & $10 \mathrm{Apr}$ & 0225 & 103.6 & 108.6 & 5.0 & 103.6 & 107.6 & 3.40 & 68 \\
\hline $14 \mathrm{R}$ & $10 \mathrm{Apr}$ & 0805 & 108.6 & 113.2 & 4.6 & 108.6 & 113.8 & 3.75 & 82 \\
\hline $15 R$ & $10 \mathrm{Apr}$ & 1225 & 113.2 & 118.2 & 5.0 & 113.2 & 116.9 & 2.86 & 57 \\
\hline $16 \mathrm{R}$ & $10 \mathrm{Apr}$ & 1750 & 118.2 & 122.8 & 4.6 & 118.2 & 122.0 & 2.67 & 58 \\
\hline $17 R$ & $10 \mathrm{Apr}$ & 1845 & 122.8 & 127.8 & 5.0 & 122.8 & 123.0 & 0.24 & 5 \\
\hline $18 \mathrm{R}$ & $10 \mathrm{Apr}$ & 2135 & 127.8 & 132.4 & 4.6 & 127.8 & 129.5 & 1.25 & 27 \\
\hline $19 R$ & $11 \mathrm{Apr}$ & 0330 & 132.4 & 137.4 & 5.0 & 132.4 & 134.6 & 1.75 & 35 \\
\hline $20 \mathrm{R}$ & $11 \mathrm{Apr}$ & 0720 & 137.4 & 141.9 & 4.5 & 137.4 & 141.2 & 3.02 & 67 \\
\hline $21 R$ & $11 \mathrm{Apr}$ & 1035 & 141.9 & 146.9 & 5.0 & 141.9 & 145.3 & 2.89 & 58 \\
\hline $22 \mathrm{R}$ & $11 \mathrm{Apr}$ & 1435 & 146.9 & 151.5 & 4.6 & 146.9 & 150.6 & 2.85 & 62 \\
\hline $23 R$ & $11 \mathrm{Apr}$ & 1855 & 151.5 & 153.5 & 2.0 & 151.5 & 153.7 & 1.71 & 86 \\
\hline $24 R$ & $11 \mathrm{Apr}$ & 2335 & 153.5 & 156.5 & 3.0 & 153.5 & 156.2 & 2.56 & 85 \\
\hline $25 R$ & $12 \mathrm{Apr}$ & 0140 & 156.5 & 161.1 & 4.6 & 156.5 & 157.7 & 1.15 & 25 \\
\hline $26 R$ & $12 \mathrm{Apr}$ & 0645 & 161.1 & 164.1 & 3.0 & 161.1 & 165.0 & 3.27 & 109 \\
\hline
\end{tabular}


Table T1 (continued).

\begin{tabular}{|c|c|c|c|c|c|c|c|c|c|}
\hline \multirow[b]{2}{*}{ Core } & \multirow[b]{2}{*}{$\begin{array}{l}\text { Date } \\
(2011)\end{array}$} & \multirow[b]{2}{*}{$\begin{array}{l}\text { Time } \\
(\mathrm{h})\end{array}$} & \multicolumn{2}{|c|}{ Depth DSF $(m)$} & \multirow{2}{*}{$\begin{array}{l}\text { Interval } \\
\text { advanced } \\
\text { (m) }\end{array}$} & \multicolumn{2}{|c|}{ Depth CSF $(m)$} & \multirow{2}{*}{$\begin{array}{l}\text { Length of core } \\
\text { recovered } \\
\text { (m) }\end{array}$} & \multirow[b]{2}{*}{$\begin{array}{l}\text { Recovery } \\
\text { (\%) }\end{array}$} \\
\hline & & & $\begin{array}{l}\text { Top of cored } \\
\text { interval }\end{array}$ & $\begin{array}{l}\text { Bottom of } \\
\text { cored interval }\end{array}$ & & $\begin{array}{l}\text { Top of cored } \\
\text { interval }\end{array}$ & $\begin{array}{l}\text { Bottom of } \\
\text { cored interval }\end{array}$ & & \\
\hline \multicolumn{10}{|c|}{ 334-U1381B- } \\
\hline $1 \mathrm{R}$ & $12 \mathrm{Apr}$ & 0955 & 0.0 & 9.4 & 9.4 & 0.0 & 4.7 & 4.70 & 50 \\
\hline $2 \mathrm{R}$ & $12 \mathrm{Apr}$ & 1040 & 9.4 & 19.3 & 9.9 & 9.4 & 14.6 & 5.21 & 53 \\
\hline $3 R$ & $12 \mathrm{Apr}$ & 1120 & 19.3 & 29.0 & 9.7 & 19.3 & 25.4 & 6.07 & 63 \\
\hline 41 & $12 \mathrm{Apr}$ & 1350 & & & $\star \star \star \star \star \star$ Drillec & om 29.0 to 50. & $00 \mathrm{~m} \mathrm{DSF}^{\star \star \star \star \star \star}$ & & \\
\hline 42 & $12 \mathrm{Apr}$ & 1700 & & & 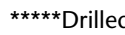 & om 50.0 to 70. & $.0 \mathrm{~m} \mathrm{DSF} F^{\star \star \star \star *}$ & & \\
\hline \multirow[t]{3}{*}{43} & $12 \mathrm{Apr}$ & 1805 & & & $* * * * *$ Drillec & om 70.0 to 90. & $0 \mathrm{~m} \mathrm{DSF}^{* * * * *}$ & & \\
\hline & & & \multirow{2}{*}{\multicolumn{2}{|c|}{$\begin{array}{l}\text { Advanced total: } \\
\text { Total interval cored: }\end{array}$}} & 254.1 & & & 89.84 & 50 \\
\hline & & & & & 193.1 & & & & \\
\hline
\end{tabular}

$\mathrm{DRF}=$ drilling depth below rig floor, $\mathrm{DSF}=$ drilling depth below seafloor, $\mathrm{CSF}=$ core depth below seafloor. $\mathrm{R}=\mathrm{RCB}$ core, $1,2,3=$ drilled intervals Time is Universal Time Coordinated. 
Table T2. Calcareous nannofossil faunal distribution, Hole U1381A.

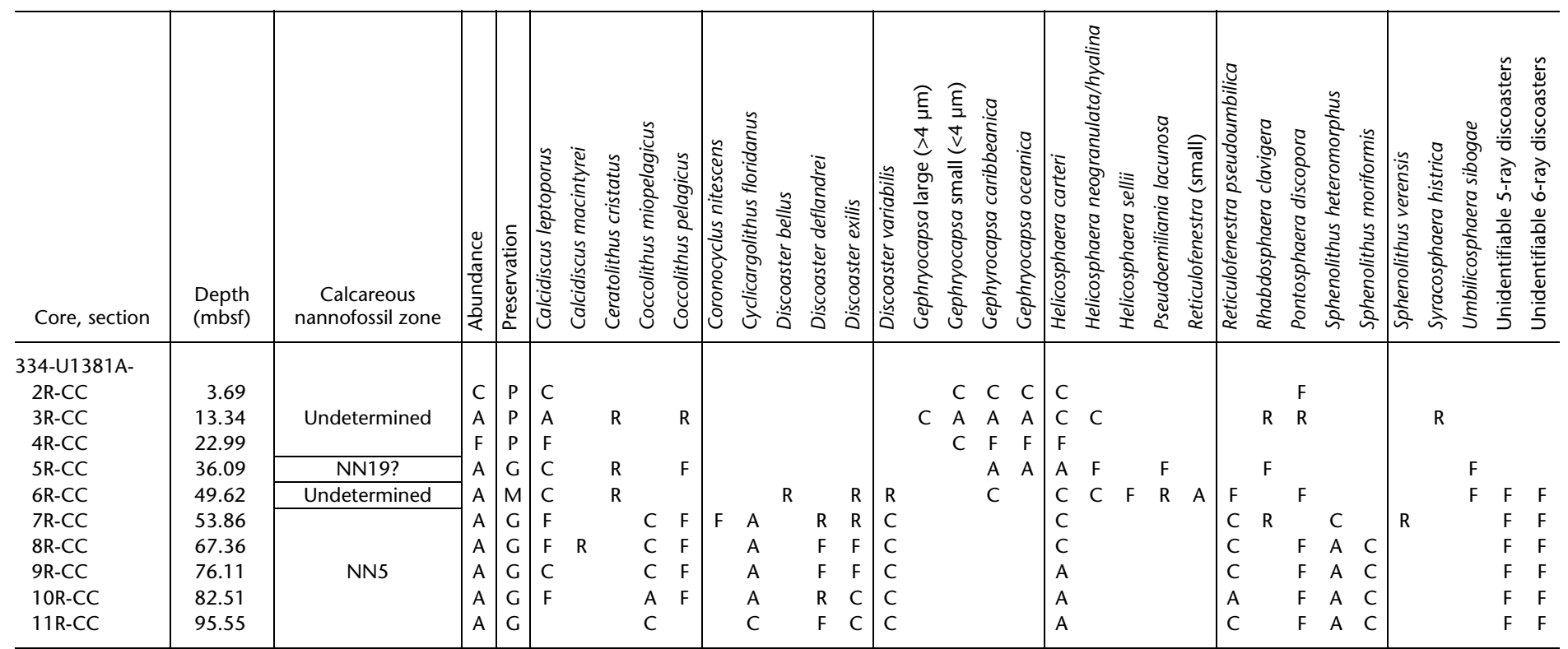

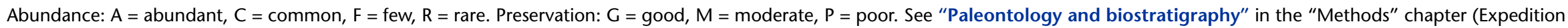
334 Scientists, 2012) for abundance and preservation definitions. 
Table T3. Planktonic foraminiferal faunal distribution, Hole U1381A.

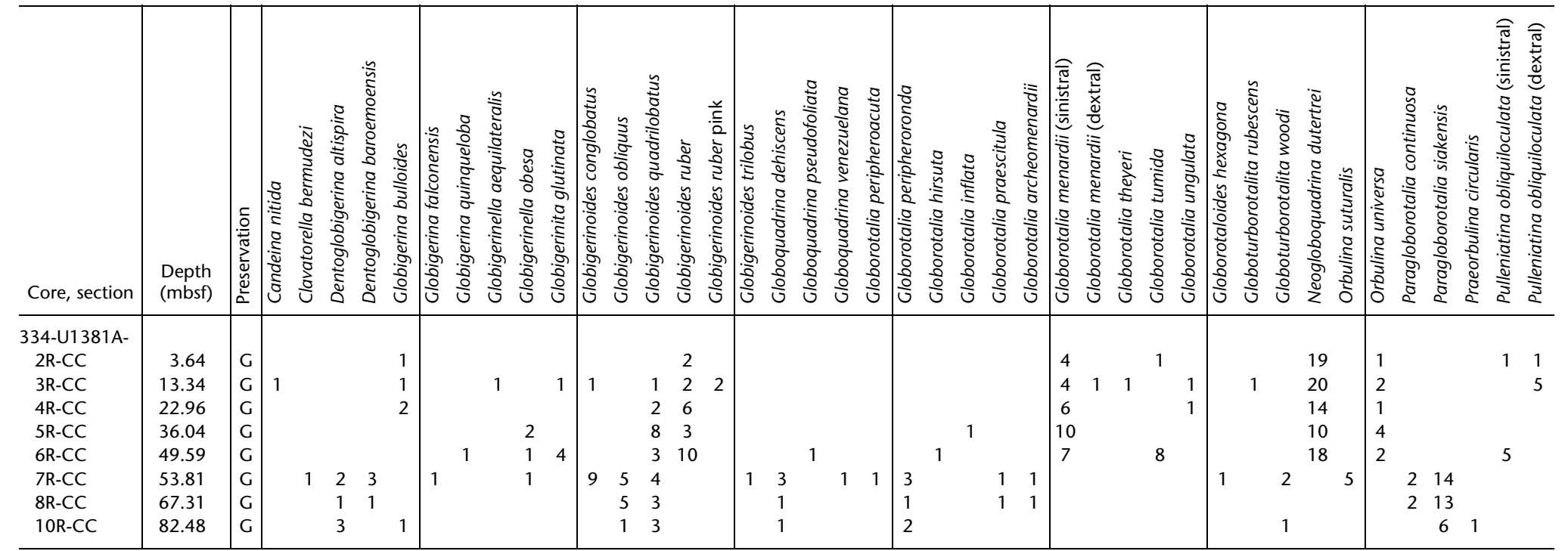

Preservation: $\mathrm{G}=$ good. See "Paleontology and biostratigraphy" in the "Methods" chapter (Expedition 334 Scientists, 2012) for preservation definitions. 


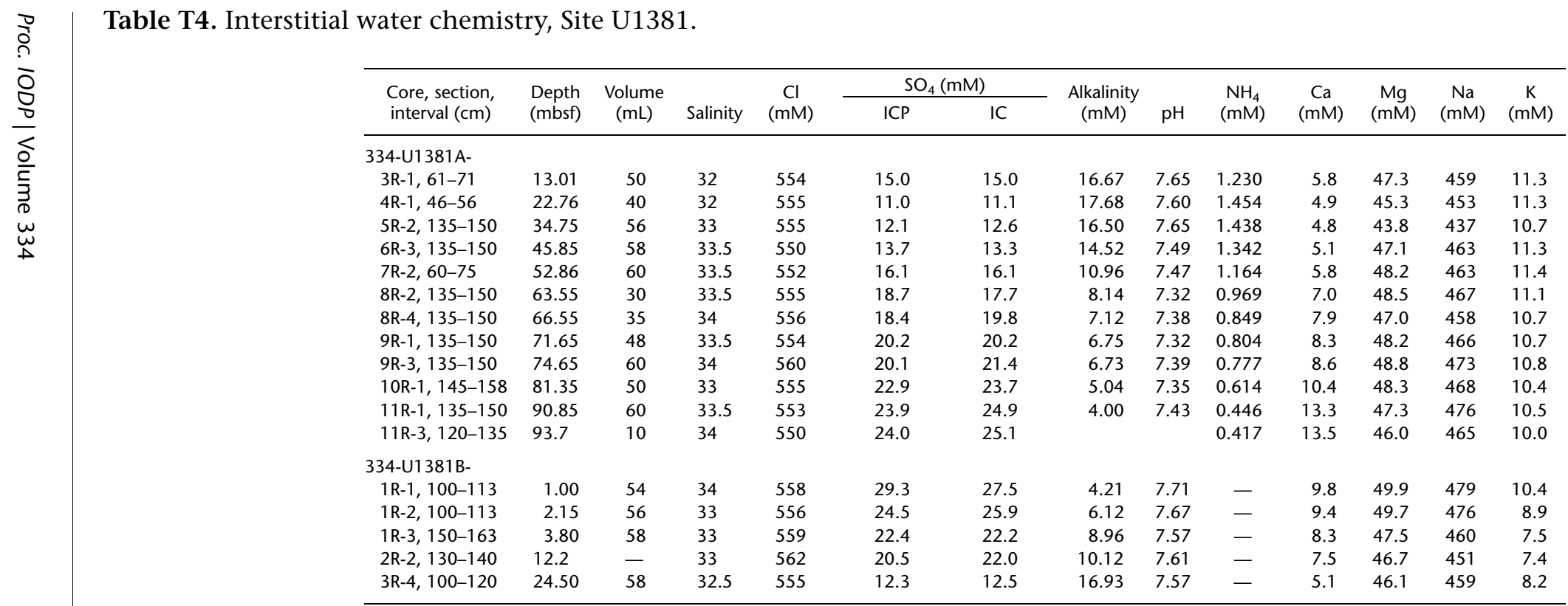


Table T5. Summary of SET temperature measurements, Hole U1381B.

\begin{tabular}{lcccccccc}
\hline & $\begin{array}{c}\text { Depth } \\
\text { Core }\end{array}$ & $\begin{array}{c}\text { BWT } \\
(\mathrm{mbsf})\end{array}$ & $\begin{array}{c}\left.{ }^{\circ} \mathrm{C}\right) \\
(\mathrm{s})\end{array}$ & $\begin{array}{c}\text { Start fit } \\
(\mathrm{s})\end{array}$ & $\begin{array}{c}\text { End fit } \\
(\mathrm{s})\end{array}$ & $\begin{array}{c}\text { Time } \\
\text { measurement } \\
(\mathrm{min})\end{array}$ & $\begin{array}{c}\text { Equilibrium } \\
\text { temperature } \\
\left({ }^{\circ} \mathrm{C}\right)\end{array}$ & Remark \\
\hline 334-U1381B- & & & & & & & & \\
$3 \mathrm{R}$ & 30.0 & 2.3 & 3503 & 343 & 499 & 3.3 & 9.7 & Poor \\
41 & 51.0 & 2.5 & 2568 & 207 & 550 & 5.7 & 13.6 & Poor \\
42 & - & - & - & - & - & - & - & - \\
43 & - & - & - & - & - & - & - & - \\
\hline
\end{tabular}

SET $=$ sediment temperature tool. BWT $=$ bottom water temperature. $-=$ not measured. 